\title{
O paradoxo das Palmas: análise do (des)uso da moeda social no "bairro da economia solidária"
}

\author{
ARIÁDNE SCALFONI RIGO \\ Universidade Federal da Bahia / Escola de Administração, Salvador - BA, Brasil
}

genauto Carvalho de França Filho

Universidade Federal da BaHIA / Escola de AdMinistração, SAlVAdor - BA, BrasiL

\begin{abstract}
Resumo
Os diferentes contextos e usos de moedas sociais no cenário nacional e internacional têm estimulado estudiosos a buscar compreender as especificidades de cada experiência. A moeda social mais conhecida no Brasil, a Palmas, criada pelo Banco Palmas em Fortaleza, encontrase atualmente em uma situação paradoxal: após quinze anos, sua circulação tem diminuído notavelmente entre os atores do território ao mesmo tempo que o consumo no bairro se mantém elevado. Neste trabalho investiga-se o circuito constituído pelo uso da Palmas para compreender seu fluxo no território e o progressivo processo de desuso. A reflexão sobre a experiência do uso da moeda social baseia-se, aqui, na noção de moeda da antropologia econômica e da teoria da dádiva. Para além da situação são propostas reflexões entendidas como pertinentes para pensar as moedas sociais dos Bancos Comunitários de Desenvolvimento (BCDs) no país. As estratégias da pesquisa assumiram um caminho multimetodológico e estão resumidas em duas fases. A primeira consistiu numa imersão etnográfica no Banco Palmas em janeiro de 2012. A segunda fase consistiu no mapeamento detalhado do circuito monetário alternativo do território por meio da construção gráfica deste utilizando um software de análise de redes sociais. A reflexão delineada com base na investigação aponta para a construção de uma filosofia de uso das moedas sociais apoiada na confiança dos atores locais nas ações do Banco Palmas. No nível mais concreto, identifica-se que a manutençao do circuito tem ocorrido mais pela sua carga simbólica e política do que pela satisfação das necessidades econômicas.
\end{abstract}

Palavras-chave: Moeda Social. Banco Comunitário. Banco Palmas.

\section{The Palmas' paradox: analysis of social currency in the "neighborhood of the solidarity economy"}

\section{Abstract}

The use of social currency in national and international contexts has encouraged scholars to understand its specificities. The most known social currency in Brazil -Palmas- created by Banco Palmas in Fortaleza, presents a paradoxical situation: after fifteen years, its circulation has significantly decreased within its territory while the consumption remains high. This article investigates the circulation of Palmas to understand its flow in the territory and its gradual reduction of use. The article reflects on this experience based on the notion of currency from economic anthropology and from the theory of the gift. The analysis here goes beyond the case of Palmas and present insights able to contribute to the debate on social currency of the Community Development Banks (CDBs) in Brazil as a whole. The research strategies were multi-methodological and can be summarized in two phases. The first phase was an ethnographic immersion in Banco Palmas in January 2012. The second phase was the mapping of monetary circulation in the territory (network analysis tools were used). The results from this research indicate the construction of a philosophy of the use of social currencies by CDBs. The use of the social currency is supported by the confidence of local actors in the actions of Banco Palmas. On a more concrete level, it was identified that the circulation maintenance depends more on symbolic and political senses than on the satisfaction of economic needs.

Keywords: Social Currency. Community Bank. Banco Palmas.

\section{La paradoja de Palmas: análisis del des(uso) de la moneda social en el "barrio de la economía solidaria"}

\section{Resumen}

Los diferentes usos de la moneda social en los contextos nacionales e internacionales han estimulado a los estudiosos a intentar comprender sus especificidades. La moneda social más conocida en Brasil-denominada Palmas y creada por el Banco Palmas, en Fortaleza- presenta actualmente una situación paradójica: después de quince años, su circulación se ha reducido significativamente dentro del territorio, mientras que el consumo en general se mantiene alto. Este trabajo investiga el circuito constituido por el uso de la moneda Palmas para entender su flujo en el territorio y el proceso gradual de desuso. La reflexión sobre la experiencia del uso de la moneda social se basa, aquí, en la noción de moneda de la antropología económica y de la teoría de la dádiva. Más allá de la descripción de la situación, se proponen reflexiones pertinentes a las monedas sociales de los bancos de desarrollo local (BCD-Bancos Comunitários de Desenvolvimento) en Brasil. Las estrategias de investigación fueron multimetodológicas y pueden resumirse en dos fases. La primera consistió en una inmersión etnográfica en el Banco Palmas, en enero de 2012. Y la segunda, en el mapeo detallado del circuito monetario alternativo en el territorio (con la utilización de un software de análisis de redes sociales). Los resultados de esta investigación indican la construcción de una filosofía de utilización de las monedas sociales apoyada en la confianza de los actores locales en las acciones del Banco Palmas. En un nivel más concreto, se identificó que el mantenimiento del circuito depende más de su peso simbólico y político que de la satisfacción de las necesidades económicas.

Palabras clave: Moneda Social. Banco de desarrollo local. Banco Palmas. 


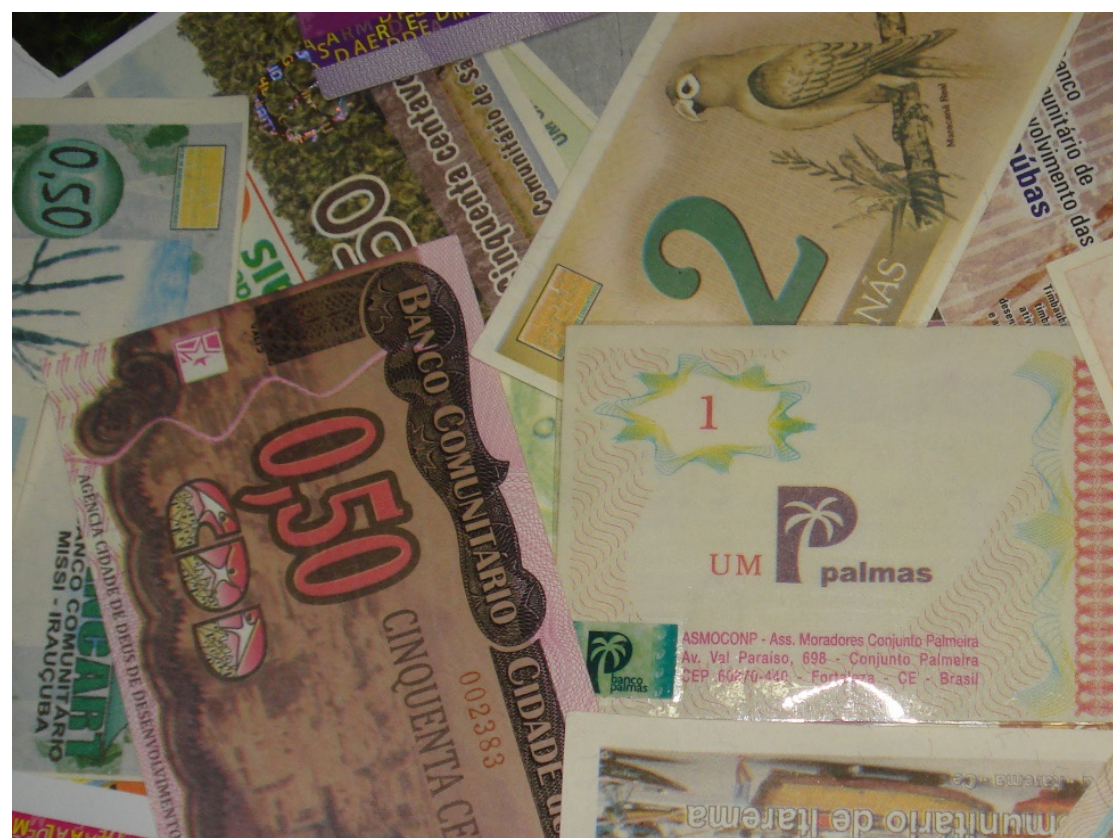

\section{INTRODUÇÃO: O CONTEXTO E O INTUITO}

Em Fortaleza, Ceará, ao chegar na rua Valparaíso, pela Travessa Edilson Candeia no sentido Messejana-Conjunto Palmeira, o visitante lê, num grande muro branco à sua frente, a frase: "Conjunto Palmeira, o bairro da economia solidária". Alguns metros à frente, atravessando a rua Valparaíso, número 698, está localizado o Banco Palmas, famoso no Brasil e no mundo pela criação de uma moeda social circulante local e por uma inovadora iniciativa pautada na concessão de microcrédito aos moradores do bairro. Em cerca de 240 empreendimentos localizados no Conjunto Palmeira, os moradores podem fazer suas compras usando um papel moeda diferente - a Palmas -, que é aceito e possui o mesmo valor que o real. Hoje, ao andar pelas principais ruas do Conjunto Palmeira, pode-se identificá-lo como um bairro popular, com ruas asfaltadas, mercadinhos e mercados maiores, farmácias, salões de beleza, armarinhos, lanchonetes e restaurantes. "Tudo o que criaram no Palmeira foi por necessidade", diz o senhor Augusto, com 62 anos, residente no bairro desde 1976, em entrevista a um grupo de alemães que veio conhecer a experiência do Banco Palmas em janeiro de 2012. A história da criação da moeda social aponta também que, juntamente com a necessidade, os moradores precisaram de inventividade para superar a pobreza e as dificuldes do território.

Algumas experiências internacionais de uso de moedas sociais são notórias. Os Local Exchange Trading Systems (LETSs), criados originalmente em 1983, em uma vila do Canadá, constituiram-se uma tentativa de amenizar os efeitos de uma crise econômica gerada pela transferência de uma base aérea para outra região (BÚRIGO, 2002; MENEZES, 2007). De acordo com Lietaer (2001 apud MENEZES, 2007), mais de 2.500 LETSs encontravam-se distribuídos pelo mundo no início do século XXI, sobretudo na Inglaterra e no Canadá. Os Time Dollars, por exemplo, diferenciam-se dos LETSs por utilizarem a moeda "tempo". Este sistema surgiu em 1980, nos Estados Unidos, tendo por intuito amenizar a falta de certos serviços provocada pelos cortes nos gastos do governo com o bem-estar social (LIETAER e KENNEDY, 2010; MENEZES, 2007). As experiências similares aos LETSs canadenses são denominadas SELs (Systèmes d'Échange Local) na França. A principal diferença entre os LETSs e oS SELs é que nestes últimos usam-se, majoritariamente, moedas virtuais (BLANC, 1998; LIETAER e KENNEDY, 2010; MENEZES, 2007). Os primeiros SELs foram criados a partir de 1994, e hoje encontram-se distribuídos em várias cidades francesas. Cada SEL cria sua moeda e seu sistema de troca.

\footnotetext{
* Fonte da imagem: Acervo pessoal (Janeiro, 2012).
} 
Também na França, o sistema SOL tem se destacado. O SOL é uma moeda complementar, comum a vários territórios franceses, com diversas finalidades: possibilita não apenas a compra de bens e serviços nas empresas participantes, mas também o intercâmbio de tempo e de conhecimento entre os membros e a valorização e o estímulo de práticas ecológicas, sociais e solidárias. Dentro desse movimento, a moeda Sol-Violette foi lançada em 2011 em três bairros da cidade de Toulouse (Centre Ville, Rangueil e Grand Mirail). Tem-se destacado e redirecionado o sistema SOL para a criação de moedas sociais localizadas que promovem a articulação entre as diferentes experiências (RIGO, 2013). Nos países germanófonos (Alemanha, Áustria e Suíça), uma rede de moedas regionais denominada de Movimento Régio foi criada em 2003 tendo por intuito estimular a troca de experiências entre os diferentes sistemas régios. Em 2008, esta rede contava com mais de 63 sistemas de moedas regionais: 28 estavam em pleno funcionamento e 35 em fase de lançamento e constituição (LIETAER e KENNEDY, 2010). As primeiras iniciativas das moedas regionais na Alemanha estão relacionadas às zonas rurais; uma das mais conhecidas é a moeda regional Chiemgauer.

Muitos sistemas de uso de moedas sociais e complementares surgiram por meio de práticas dos clubes de troca que estimulam a troca de bens e serviços entre as pessoas. Os clubes de troca originaram-se na Argentina em 1995 e se difundiram rapidamente, aumentando o número de sócios e o número de clubes de troca pelo país. Acabou se tornando uma alternativa em meio à crise dos anos 2000 e deu origem a uma economia paralela. De fato, "os argentinos decidiram tomar pelas mãos a organização do seu país para sobreviverem" (FAIRE MOUVEMENT, 2011, p. 136). Para se ter uma ideia do contexto argentino na época, antes dos anos 2000, havia 85 clubes; em 2000, chegou-se à marca de 400. Em 2001 e 2002, auge da crise, existiam respectivamente 1.800 clubes de troca com 800 mil membros e 5.000 clubes com 2 milhões de membros. Mas as várias fraudes, como as relativas aos problemas contábeis e de falsificação de moedas, acabaram por provocar descrédito e distanciamento da ideologia solidária que the deu origem. Atualmente, existem aproximadamente 20 clubes com 4.000 membros, os quais possuem um caráter local e buscam uma integração em rede (FAIRE MOUVEMENT, 2011).

Os diferentes contextos e usos de moedas sociais e complementares no cenário nacional e internacional têm estimulado estudiosos em buscar compreender as especificidades de cada experiência e as características concernentes a um movimento que parece existir em prol do uso de moedas sociais como instrumento de desenvolvimento local ou de contestação político-ideológica. Economistas, antropólogos, sociólogos e estudiosos do campo da economia social e solidária de modo geral se debruçam sobre este intenso movimento, buscando identificar semelhanças e diferenças no que diz repeito aos objetivos, atores envolvidos, esquemas (design) e modos de gestão destes circuitos monetários alternativos (FREIRE, 2009; 2011; LIETAER e KENNEDY, 2010; MARTIGNONI, 2012; MENEZES, 2007; SCHROEDER, MYIAZAKI e FARE, 2011; SOARES, 2006; 2009).

Especificamente sobre o papel do uso de moedas sociais e complementares para o desenvolvimento de territórios, poucos estudos podem ser encontrados. No entanto, Fare (2011) e Fare, Freitas e Meyer (2013) propuseram esta discussão apontando a importância de se compreenderem as experiências de uma maneira territorizalizada, ou seja, considerando as especificidades de cada contexto. Nestes estudos, o contexto imprime à experiência limites e potencialidades para suplantar os problemas locais por meio do uso de circulantes locais. Encontramos ainda o estudo de Soteropoulou (2012), que, dentre outras coisas, analisa o uso das moedas sociais com base nas crises econômicas, centrando sua discussão no caso da Grécia.

Desde o início da criação do Banco Palmas em 1998 e da moeda Palmas em 2002, alguns estudos dedicaram-se a descrever e interpretar esta experiência singular de busca endógena pelo desenvolvimento territorial (BORGES, 2011; FRANÇA FILHO e SILVA JUNIOR, 2009; FRANÇA FILHO, RIGO, SILVA et al., 2012; FREIRE, 2011; SILVA JÚNIOR, 2004; RIGO, 2013). A experiência também tem chamado a atenção de praticantes e pesquisadores estrangeiros (ANDREW, 2011; MEYER, 2012). No entanto, os estudos não têm se debruçado sobre a questão do progressivo desuso da moeda social no território. A tensão entre a ampla difusão da experiência do Banco Palmas e da sua moeda social no Brasil (e em alguns países) e o desuso da Palmas no Conjunto Palmeira levaram ao aprofundamento das informações sobre a situação aqui denominada "paradoxal". Isso porque se nota que, ao mesmo tempo que o consumo no bairro se mantém elevado, o desuso da moeda social mostra-se progressivo entre moradores e comerciantes. Ora, se o intuito do uso da moeda social é justamente elevar a circulação de riqueza dentro do território, por que o uso da Palmas diminui enquanto o consumo interno se mantém elevado?

As moedas sociais são circulantes locais criados pelos Bancos Comunitários de Desenvolvimento (BCDs) e estão restritos a um determinado território de atuação. $O$ intuito do uso de um circulante local é incentivar a manutenção da circulação dos recursos no local. No caso do Conjunto Palmeira, na análise do consumo no bairro, verifica-se que, mesmo com a diminuição 
do uso da Palmas, seu nível se mantém elevado. De acordo com o mapeamento da produção e do consumo empreendido pelo Banco Palmas, a cada dois anos, entre $93 \%$ e $95 \%$ dos moradores consomem no próprio bairro. Então teria a moeda Palmas cumprido seu papel e estaria prestes e desaparecer? Para o coordenador do Banco Palmas, Joaquim de Melo Neto, o uso das moedas sociais deve ser visto como um mecanismo, mesmo que temporário, de estímulo ao consumo interno e à valorização das coisas do lugar: "[...] as moedas sociais não podem, então, ser vistas de forma apologética ou como uma panacéia, mas como um instrumento com papéis a cumprir" (Entrevista, jan. 2012).

Diante deste "paradoxo" e da importância nacional desta moeda social, investiga-se neste trabalho o circuito monetário constituído pelo uso da Palmas a fim de compreender seu fluxo no território e o processo de desuso. Várias lentes teóricas poderiam servir nesta empreitada. Neste trabalho buscou-se refletir sobre o uso da moeda Palmas no território com base na teoria da dádiva. Isso porque, segundo Blanc (1998), a ideia maussiana de "fato social total", base da teoria da dádiva, permite reinserir, na discussão sobre a moeda, as problemáticas econômica, política, sociológica e antropológica, e enriquecê-la, considerando que uma diversidade de instrumentos pode dispor de qualidades monetárias (BLANC, 1998). Este exercício teórico-analítico permitiu ir além da descrição da situação e refletir aspectos considerados interessantes a respeito das moedas sociais de BCDs no país. Para isso, teve-se como base, essencialmente, Caillé (2002a; 2002b) e a compreensão da teoria da dádiva como paradigma e como fenômeno em si.

As contribuições das análises e dos resultados deste artigo são mais de ordem prática do que teórica. Isso porque a Palmas é a primeira moeda social de bancos comunitários do país e inspira a constituição da rede brasileira de bancos comunitários, que hoje conta com 103 experiências. Estas experiências, juntamente com apoio do Estado e com a ação direta de Entidades de Apoio e Fomento (EAF), delineiam hoje no Brasil uma política pública de finanças solidárias com apoio direto do governo federal (via Secretaria Nacional de Economia Solidária) e de alguns governos locais. Além disso, os custos que envolvem a manutenção da circulação das moedas sociais sugerem que investigações mais aprofundadas sejam empreendidas no campo destas práticas.

\section{O CAMINHO METODOLÓGICO}

As estratégias da pesquisa assumiram um caminho multimetodológico e se resumem em duas grandes fases. A primeira consistiu numa imersão etnográfica no Banco Palmas em janeiro de 2012 (09/01/2012 a 03/02/2012). Esta imersão permitiu viver um pouco a dinâmica do bairro e entender sua história. O Conjunto Palmeira compõe a região do Alto Jangurussu, juntamente com mais dez bairros; possuía, à época, cerca de 35 mil habitantes. A região possui cerca de 300 mil habitantes e está entre uma das mais pobres da cidade (INSTITUTO PALMAS, 2011). Com a imersão etnográfica foi possível compreender o modo de funcionamento do Banco Palmas, acompanhar o seu dia a dia, realizar entrevistas com pessoas-chave da organização e com representantes de outras organizações locais e lideranças comunitárias, principalmente aquelas que ajudaram a construir a história da comunidade. Essas entrevistas tiveram um caráter aberto e aconteciam à medida que a necessidade de novas informações surgiam (total de 18 entrevistas). 0 período da pesquisadora no Banco Palmas permitiu o acompanhamento de alguns processos internos da organização: como a concessão de crédito, o trabalho nos caixas e o desenvolvimento de alguns projetos sociais. Não foram privilegiados os detalhes financeiros do microcrédito do Banco Palmas, uma vez que o foco era a moeda social. A respeito desta, foi possível obter dados acerca de criação, emissões e circulação por meio de registros e entrevistas. Foi possível também conversar com pessoas na comunidade e comerciantes locais sobre seu uso e significados.

Essa fase da pesquisa deu origem a um caderno de campo detalhado constituído tanto por informações dos sujeitos quanto por impressões da pesquisadora. No entanto, essas informações, apesar de delinear o paradoxo, instigou a busca por mais detalhes sobre sua circulação no território. Assim, foi necessário um retorno com uma estratégia de investigação mais apropriada ao entendimento do circuito monetário. Isso ocorreu em uma segunda fase da pesquisa, em outubro de 2013.

A segunda fase consistiu no mapeamento detalhado do circuito monetário alternativo do território por meio da utilização de ferramentas gráficas da análise de redes sociais. A visualização do circuito monetário por meio do software Ucinet 6 para análise de redes possibilitou compreender melhor os atores (nós) e as relações entre eles (laços) dentro do circuito. Os cálculos matemáticos que podem ser realizados para toda análise de rede não se mostraram úteis naquele momento e intuito. 
Diante disso, não se julgou necessário recorrer à vasta literatura sobre redes sociais neste trabalho. Mapeou-se quase a totalidade dos empreendimentos que compõem a rede de aceitação da moeda. As análises abrangeram 99 empreendimentos e 95 moradores que usam e conhecem a moeda social. Durante toda a pesquisa, o posicionamento etnográfico mostrou-se adequado aos propósitos da construção deste trabalho e guiou a pesquisa em campo e as interpretações das informações decorrentes. Este posicionamento se caracteriza pelo movimento constante que aproxima os "polos" sujeito-objeto, particular-geral e objetividade-subjetividade (ANDION e SERVA, 2006). Ainda como posicionamento, a trilha metodológica adotada assume o referencial teórico apenas como uma interpretação possível.

Este trabalho está organizado em quatro partes subsequentes a esta introdução. Na primeira, introduz-se a concepção de moeda proveniente da antropologia econômica para, em seguida, indicar-se a teoria da dádiva como um possível arcabouço teórico que permitiu elaborar reflexões ao final do texto. Neste ponto foram fundamentais as ideias de Caillé (2002b) em torno de uma compreensão mais contemporânea do entendimento desta teoria. Vale ressaltar que o arcabouço teórico não muniu esta pesquisa com categorias de análise prontas e objetivas para em seguida serem confrontadas com os achados. As reflexões partiram de um entendimento geral da teoria da dádiva, particularmente as noções de interesse e desinteresse e da tríplice ação dar-receber-retribuir. Após compreensão da situação paradoxal que se propôs, aqui, chega-se à reflexão sobre interpretações possíveis (embora não únicas).

As três seções após o arcabouço teórico têm como foco a realidade: o caso da circulação da moeda Palmas. Na primeira foram abordadas sua origem e sua evolução no território; na segunda foi delimitado "o paradoxo", ou seja, a situação particular e curiosa do desuso da moeda social no território; e na terceira, são apresentadas as análises do circuito monetário constituído pelo Banco Palmas - esta sessão é densa e descritiva, mas permite compreender em detalhes o fenômeno em análise. À guisa de considerações finais, reflexões baseadas no arcabouço teórico escolhido são apresentadas na última parte do texto.

\section{OS USOS DE MOEDAS NA ANTROPOLOGIA ECONÔMICA E O PARADIGMA DA DÁDIVA COMO UMA INTERPRETAÇÃO POSSÍVEL}

Conta-se que, nos primórdios, as sociedades viviam sob a égide de um comunismo primitivo, no qual se repartiam as riquezas entre seus membros. Com o desenvolvimento dessas comunidades, os contatos entre elas foram inevitáveis e a consequência natural foi uma forma pura de troca, chamada de escambo, por meio da qual os objetos (artefatos, produtos agrícolas, animais etc.) eram comparados uns aos outros de forma natural e trocados entre si. Em seguida, o escambo se tornou complexo e se ampliou de tal forma que surgiu um meio de troca para torná-lo mais cômodo e "justo". Este meio de troca - a moeda - tornou-se um mecanismo para expressar os valores das coisas, sendo possível, inclusive, reservá-la para trocas futuras (AGLIETTA e ORLÉAN, 1990).

Para alguns estudiosos, a história resumida acima é uma "fábula" narrada pela economia para explicar o surgimento da moeda. Em uma abordagem antropológica da economia, essa é a origem da moeda moderna, a que conhecemos hoje como moeda de mercado, mas não é a origem da moeda, em si, como prática e como instituição (AGLIETTA e ORLÉAN, 1990; CAILLÉ, 1995). Caillé (1995) é um dos estudiosos que também entendem como "fábula" tal narrativa e não vê resultado no esforço da economia para entender que o que há por trás da moeda é a sede de riqueza. Para a economia, é simples: a moeda é um "truque técnico" voltado ao desenvolvimento das trocas que são necessárias para o enriquecimento. Por óbvio, tais técnicas foram se aperfeiçoando, passando do boi e do camelo para as letras de crédito, a moeda escritural, o cheque e o cartão de crédito etc. Mas, para Caillé (1995), isso não explica o valor intrínseco da moeda. Ela vale o que nós cremos que ela vale. Neste mesmo sentido, mas recorrendo a Polanyi (2011), a noção de moeda assume amplitude tanto em termos históricos quanto em termos de uso:

[...] as dívidas e as obrigações são fenômenos primitivos que existiam antes da existência do mercado, e as economias de galpões de estocagem da antiguidade conheciam previsões financeiras e a contabilidade bem antes da utilização da moeda como meio de troca se tornar importante, (POLANYI, 2011, p. 83). 
Além disso, uma mesma sociedade pode se utilizar de uma pluralidade de modos de troca e circulação de bens e serviços (SERVET, 1993). Citando o rico exemplo da Grécia Antiga, Aglietta e Orléan (1990) explicam que os objetos e seus respectivos valores dependiam enormemente do reconhecimento mútuo entre pessoas, do tipo de objeto e de status entre pessoas diferentes, formando categorias de valores de uso numa estrutura de relações solidárias relativamente complexa. Por exemplo, objetos que eram fruto de roubos de guerra (chamados ktémata) circulavam em festas e jogos - poderiam ser destruídos em festas e reforçavam a fraternidade significando as necessidades básicas da vida social de toda comunidade. Objetos trabalhados por artesãos (os agalmata), como joias e vasos, eram muito valiosos e frequentemente serviam como oferendas aos mortos e aos deuses. Ainda, "objetos" vivos como mulheres e escravos (os probata) tinham o papel de estabelecer laços duradouros quando ofertados e eram geralmente usados em rituais de sacrifício. Outros objetos eram provenientes da terra, como os alimentos (os chrémata) e os metais (os keimélia). Já os metais, utilizados para elaboração de armas, eram associados a coisas maléficas e deveriam ser cuidadosamente manipulados (eram geralmente sacralizados). Tais exemplos, como lembram Aglietta e Orléan (1990), eram vinculados à pessoa do doador, não contendo a impessoalidade, o anonimato e a homogeneidade da moeda moderna.

Na concepção de Théret (2008), a moeda é concomitantemente linguagem, objeto e instituição. É, ao mesmo tempo, sistema de contas, instrumento de pagamento e regras de moedagem. Desse modo, está muito longe de ser apenas um meio de troca, como indicam os mais comuns significados na teoria econômica; ou um sistema de regras, como na economia institucionalista. "Ela é um fato social total que tem simultaneamente estas três dimensões, o fenômeno da moeda sendo ao mesmo tempo econômico, político e simbólico" (THÉRET, 2008, p. 21). Ainda para Théret (2008), a maioria das teorias sobre a moeda acaba por focar apenas um dos seus dois lados: o simbólico ou o econômico. No primeiro, ela é vista como um aspecto das relações entre os indivíduos, operando como um símbolo que faz sentido com outros símbolos do sistema, dentro do qual os significados são compartilhados e trocados. No segundo lado, ela é vista como algo desconectado das pessoas (HART, 1986 apud THÉRET, 2008).

Théret $(2008$, p. 16) sugere, então, um terceiro lado: o de "[...] uma forma institucional conectando pessoas e coisas, um sistema de regras que faz com que 'a coisa distinta das pessoas' que foi escolhida para representar certas relações entre pessoas o faça legitimamente". A moeda, então, pode ser vista como um emaranhado de dívidas e créditos na sociedade que a forma e a constrói. A moeda é "[...] uma representação ativa da sociedade como um todo, pois participa desde o início da sua construção" (THÉRET, 2008, p. 3).

Aqui se entende que a própria existência de moedas sociais coloca em questão alguns princípios da concepção tradicional da economia sobre a moeda moderna. Nesta concepção, a moeda é única e exclusiva, agrega um conjunto de outros instrumentos monetários e é capaz de cobrir a totalidade dos campos de práticas monetárias; além disso, a moeda é propriedade do Estado, pois ele é a autoridade monetária. As moedas complementares por si só são diversificadas e em muitos casos são endossadas pelos governos. Da perspectiva de Blanc (1998, p. 91), “[...] a análise econômica da moeda não pode, portanto, passar de uma análise antropológica e sociológica" (BLANC, 1998, p. 91).

Então, qual deve ser o ponto de partida para uma reflexão sobre a moeda e especificamente sobre as moedas sociais? Segundo Blanc (1998), a ideia maussiana de "fato social total", base da teoria da dádiva, permite reinserir, nas discussões sobre a moeda, as problemáticas econômica, política, sociológica e antropológica, e enriquecê-las, considerando que uma diversidade de instrumentos pode dispor de qualidades monetárias (BLANC, 1998).

Importa salientar que a discussão sobre o valor heurístico de uma interpretação específica da dádiva, que serviu de fundamento para a construção de outro tipo de teoria e mesmo um novo paradigma em ciência sociais, fora iniciada há mais de trinta anos por um conjunto de intelectuais reagrupados, na França, em torno de um periódico científico: a Revista do MAUSS (Mouvement Anti-Utilitariste dans les Sciences Sociales). Estes retomam a noção de dádiva tal como formulada originalmente por Marcel Mauss (sociólogo e antropólogo francês do início do século XX), em seu texto seminal Essai sur le Don, Forme et Raison de l'Échange dans les Sociétés Archaïques, e enveredam por uma severa crítica ao pensamento utilitarista vigente que subordina e reduz toda ação social a uma questão de escolha econômica racional e estratégica. Para estes teóricos, os fundamentos do social não se amparam unicamente em interesses instrumentais, regras contratuais, nem tão pouco no puro desinteresse. Tais fundamentos, por razões muito variadas, envolvem um grande simbolismo cuja interpretação requer uma compreensão fina da dinâmica muitas vezes paradoxal entre interesses utilitários e motivações substantivas 
influenciando as condutas humanas e ações coletivas. Esta perspectiva da dádiva, longe de pregar que a ausência de reconhecimento das motivações utilitárias podem condicionar a conduta dos atores individuais e coletivos, abre a possibilidade de compreensão de outros elementos, menos instrumentais e utilitários, que também podem participar da explicação sobre os comportamentos individuais e coletivos. Ainda nesta perspectiva antopológica, a dádiva é um sistema de intercâmbio, de bens ou serviços, no qual a importância da troca não está no que circula, mas nos vínculos estabelecidos por meio da relação gerada. Nesta relação, mais do que a satisfação utilitária dos bem trocados, tudo que circula é em prol da construção e manutenção dos laços sociais.

Conforme define Caillé (2002b, p. 102), a dádiva trata-se de "[...] qualquer prestação de bens ou serviços efetuada sem garantia de retorno, tendo em vista a criação, manutenção ou regeneração do vínculo social. Na relação de dádiva, o vínculo é mais importante do que o bem". É uma relação que não procura a equidade na troca, mas um sentimento de dívida espontânea, voluntária, em que as partes se sentem dispostas a doarem de uma forma incondicional, "sem garantia de retorno" (GODBOUT, 1999, p. 29). A finalidade não é a retribuição, mas quando ela existe, ela reafirma uma dívida para fortalecer os vínculos (ROSPABÉ, 1995). Evidentemente que a noção de dívida, aqui, remete ao plano da percepção numa relação intersubjetivamente compartilhada entre os indivíduos.

De fato, dessa perspectiva antropológica da dádiva, dois caminhos analíticos se desenham. Um do ponto de vista da dádiva como fenômeno em si, que permite compreender de maneira multidimensional as relações sociais; outro da perspectiva da construção (ou constatação) de um paradigma que permite a contraposição ao paradigma utilitarista.

No primeiro caminho analítico, a constatação segundo a teoria da dádiva é de que, ao lado do mercado de bens e serviços e ao lado da redistribuição de bens e serviços proporcionada pelo Estado, existe um imenso e variado número de experiências sociais, econômicas e políticas que se baseiam na construção de laços sociais e de relações de confiança, ou seja, experiências baseadas no que Caillé (2002b) chama de mecanismo da dádiva. Esta dádiva (ou dom, conforme algumas traduções), embora paradoxal (como veremos adiante), é entendida por Caillé (2002a; 2002b) como regra social primordial e se resume na tríplice ação dar-receber-retribuir, que é a própria condição da vida. Portanto, para o autor, ela é insubordinada à satisfação dos interesses pela simples busca de utilidades, por isso, antiutilitarista.

No segundo caminho analítico, a teoria da dádiva permite construir as bases para um terceiro paradigma, que se contrapõe ao paradigma individualista e ao paradigma holista (CAILLÉ, 2002a). O primeiro diz respeito ao conjunto de ideias e teorias nas ciências sociais relacionadas ao individualismo metodológico. Neste paradigma, ainda dominante nas ciências sociais, os estudos e reflexões sobre os fenômenos e as escolhas individuais se baseiam na concepção de homem egoísta, autointeressado ou racional. O segundo paradigma, que também teve seus "tempos de glória", procura explicar as ações individuais e os fenômenos sociais como resultado da dominação da estrutura social. Por exemplo, o estruturalismo e o funcionalismo são posturas holistas bem conhecidas (CAILLÉ, 2002a). Em resumo, Caillé (2002a) não critica a existência destes paradigmas, mas a pretensão deles de se intitularem como únicos para explicar a realidade. Para o autor, tais paradigmas devem ser vistos como momentos de um mesmo ciclo, o ciclo do dom e da aliança.

Os aspectos paradoxais da dádiva explorados por Caillé (2002a) são essencialmente dois e dizem respeito, de um lado, ao seu caráter simultaneamente livre e obrigado e, de outro, interessado e desinteressado. Tais paradoxos indicam uma compreensão multidimensional da ação social. O interesse diz respeito ao interesse instrumental, econômico. O que Caillé (2002a) chama de desinteresse refere-se à ordem da paixão (interesse para). Já em relação à liberdade e à obrigação, a primeira se relaciona com a espontaneidade, o lúdico, o criativo, e a segunda, com a lei moral e a coerção. Estas distinções e a consideração desta multidimensionalidade são capazes de distinguir o utilitarismo do antiutilitarismo, porque o segundo coloca uma pluralidade intrínseca à ação social e às relações sociais, bem como confere ao desinteresse e à liberdade superioridade em relação à obrigação e ao interesse.

Uma questão que se coloca é: por que "interesse" na relação de dádiva? Porque uma relação de dádiva permite também a satisfação utilitária de uma necessidade (mesmo não sendo esse o objetivo primordial da relação). Por isso uma dimensão utilitária pode estar presente, mas ela não é a única e nem a que se sobressai numa relação deste tipo. $O$ que se sobressai é o desinteresse, que, na linguagem do paradigma da dádiva, significa a necessidade de se associar com o outro, de construir aliança, de querer se vincular. Neste ponto, uma segunda questão pode surgir: mas isso não seria um interesse? Sim, mas não o da linguagem utilitária. $O$ interesse pelo outro é o interesse não utilitário (antiutilitário). É neste sentido que se pode 
afirmar, neste jogo paradoxal entre interesse e desinteresse, uma subordinação do interesse utilitário ao desinteresse ou uma subordinação do utilitário ao antiutilitário.

O paradoxo entre liberdade e obrigação na dádiva reside no fato de as pessoas agirem ao mesmo tempo de forma livre e obrigada neste sistema de dar-receber-retribuir. Isto porque, se o ato de dar produz no recebedor uma obrigação em retribuir, como um sentimento de dívida, tal obrigação é de certa forma livremente autoconsentida. Ou seja, as pessoas se obrigam livremente a retribuir aquilo que não foi dado com obrigação de retribuição. É por isso que, quando recebemos um presente, por exemplo, podemos nos sentir obrigados a retribuir, mas com uma dose considerável de liberdade de retribuímos ou não. Além da dívida, a dádiva introduz também certa dose de incerteza na relação acerca da sua continuidade ou não.

Em resumo, Caillé (2002a) argumenta que existem inúmeras situações intermediárias entre confiar ou desconfiar totalmente. Para o autor, se toda aliança visasse unicamente a fins instrumentais, não haveria confiança mútua, mas um sentimento generalizado de que todos trapaceiam, o que configuraria um estado de guerra ou de indiferença de todos contra todos. Desse modo, as alianças só podem ser estabelecidas com base em alguma incondicionalidade, e somente deste ponto é possível que surja e que se exerça a condicionalidade ou a contratualidade. Essa consideração reforça a noção exposta anteriormente de que em primeiro lugar (ou primordialmente) existem a liberdade e o desinteresse e, em segundo (ou como consequência), podem ser percebidos a obrigação e o interesse.

O paradigma do dom ou teoria da dádiva, neste trabalho, compreende o subcampo do conhecimento ou "pano de fundo" de abordagens mais específicas sobre a moeda. Com base nele encontra-se grande parte das discussões sobre a moeda no âmbito da antropologia econômica. Isso porque esse tipo de abordagem teórica busca compreender os fenômenos que não restringem seu caráter de ação à ação econômica utilitária. Esse é o entendimento que se tem, neste trabalho, sobre o uso das moedas sociais. Por um lado, elas cumprem um papel eminentemente econômico ou instrumental, já que se constituem como meio de pagamento acessível sobretudo para aqueles grupos sociais num território que não dispõe do acesso regular à moeda convencional, ou seja, as moedas sociais podem contribuir com o aumento de liquidez numa economia local e podem assim permitir a satisfação utilitária de necessidades. Por outro lado, a aceitação das moedas sociais pressupõe a construção de relações de confiança tanto entre pessoas quanto entre instituições responsáveis pela gestão desse sistema. Assim as moedas sociais requerem aceitação social, isto é, necesitam ser legitimadas. De acordo com o exposto, podemos percebê-las dotadas, antes de tudo, de alto valor simbólico, tendendo a se tornar também símbolos de identidade cultural local. É, portanto, nesta relação paradoxal entre um duplo papel, utilitário e não utilitário da moeda social, que se pode melhor comprender sua complexidade.

\section{CRIANDO E GERENCIANDO UMA MOEDA PRÓPRIA: A HISTÓRIA E A ORIGINALIDADE DO USO DA MOEDA SOCIAL PALMAS}

A moeda Palmas é a segunda versão da moeda Palmares, usada pelo Banco Palmas no clube de trocas realizado com os moradores da comunidade ainda no final dos anos 90 . Interessados em trocar produtos e serviços, os moradores se reuniam em uma feira nas dependências do Banco Palmas semanalmente, levando consigo uma série de produtos que queriam trocar. A Palmares servia apenas como um mecanismo facilitador das trocas. Sandra Magalhães, coordenadora de projetos do Banco Palmas, destacou a riqueza do processo de criação da moeda Palmares: várias assembleias foram realizadas para que, coletivamente, decidissem quais desenhos trariam e que nome teria. Para ela, "[...] o processo é muito rico, porque se cria um dinheiro, um valor. O dinheiro nos domina, então o fato de uma comunidade criar seu próprio dinheiro é um processo de empoderamento" (Entrevista, jan. 2012).

A ideia desse clube de trocas, assim como outros no Brasil, foi inspirada pela experiência argentina. Os moradores perceberam que as pessoas produziam muitas coisas e, ao mesmo tempo, precisavam de muitas outras. E assim decidiram criar seu próprio meio de pagamento e de troca, já que a maioria dos moradores não tinha a moeda oficial para comprar o que precisava. Na época, o nome Palmares foi muito significativo porque era como se chamava o principal quilombo do Brasil. A Palmares, usada apenas nos momentos do clube de trocas, foi elaborada e impressa no próprio Banco Palmas, sem que 
houvesse prevenção contra falsificações, mesmo porque, ao final de cada encontro, os produtores e consumidores devolviam as moedas que haviam recebido pelos seus produtos e serviços.

Após cerca de sete meses, os questionamentos em torno do clube de trocas e seu esvaziamento levaram à criação de uma moeda nova que traduzisse uma proposta igualmente nova. No clube de trocas, o "descasamento" entre oferta e demanda por produtos alimentícios começou a incomodar os participantes. A maioria levava para as trocas vestuário e artesanato, mas procurava por alimentos. Além disso, no clube de trocas, era difícil definir o preço das coisas que as pessoas levavam. Esse descontentamento despertou a questão: “Por que não transformamos todo o bairro num grande clube de trocas?" (Entrevista, Coordenador do Banco Palmas, jan. 2012). Desta forma, a moeda poderia ser usada em todo o bairro e o "clube" funcionaria todo o tempo. Mas, para tanto, foi necessário mudar o aspecto da moeda e passar a confeccioná-la com mecanismos de segurança para facilitar sua aceitação pelos comerciantes do bairro. Como o Banco Palmas já era conhecido no território (desde 1998) e já havia projetos que mantinham a marca "Palmas" (que fazia alusão à vegetação nativa local), decidiu-se pelo nome "Palmas" - a moeda foi criada em 2002. Como a Palmares ficava no Banco Palmas, após cada clube de trocas, o processo de substituição foi imediato.

Na nova moeda passaram a existir quatro mecanismos de segurança: a) número de série pelo qual são cadastradas; b) marca d'água, que dificulta a impressão; c) o código de barras; e d) marca para leitura ultravioleta. Todos estes mecanismos eram fundamentais não apenas para evitar falsificações, mas para que os comerciantes aceitassem a moeda. Outro mecanismo de segurança para os comerciantes e os usuários de maneira geral é o sistema de lastro. Para cada moeda social que circula na comunidade, existe seu correspondente em real nos cofres do Banco Palmas ou em conta bancária específica. Isso é particularmente importante para os comerciantes do bairro porque precisam realizar grande parte de suas compras nos bairros de seus fornecedores. Além disso, esta é também uma exigência do Banco Central do Brasil.

Nos primeiros lançamentos da Palmas no Conjunto Palmeira, apenas dois empreendimentos no bairro a aceitavam. À medida que outros empreendimentos perceberam que o movimento naqueles dois "concorrentes" estava aumentando, passaram também a aceitá-la. De acordo com a lista de cadastro do Banco Palmas, atualmente 240 estabelecimentos aceitam a Palmas no bairro e na circunvizinhança. Além do lastro e da confiabilidade na moeda, foi importante a utilização de diversos mecanismos para sensibilizar os comerciantes e os moradores do bairro sobre a importância do uso da moeda social para o território. Como relata Sandra Magalhães, "É importante que muitos comerciantes aceitem a moeda para que os consumidores saibam o que fazer com elas [onde gastar]" (Entrevista, jan. 2012).

Por isso, o Banco Palmas utilizou um conjunto de mecanismos de sensibilização e comunicação que estimularam a aceitação e circulação da moeda. Este processo de sensibilização aconteceu de forma constante por meio de uma série de mecanismos empregada pelo Banco Palmas no território, tais como vídeos, cordéis, canções, peças teatrais e até uma fotonovela com moradores do bairro. Neste processo, a comunidade foi ofertada com assuntos como economia e finanças solidárias, consumo local e moeda social, entre outros. Nota-se que os mecanismos de comunicação e sensibilização não foram criados exclusivamente para o uso da moeda, mas para as ações do Banco Palmas de modo geral (envolvendo as linhas de microcrédito, o uso do Palma Card e outras). No que tange ao uso da moeda social, a ideia era sensibilizar os comerciantes a aceitarem a moeda e as pessoas a comprarem no bairro. Nota-se, neste processo, uma clara preocupação com a dimensão de pegagogia política em tais ações, apontando para processos de mudança de cultura política no local enquanto uma dinâmica de aprendizagem lenta e gradual.

Analisando documentos sobre emissões e o uso da Palmas para o consumo no território ao longo dos últimos anos, notamos que, em janeiro de 2012, um volume de cerca de 40 mil Palmas circulava no bairro. Este volume de moeda, de acordo com o Banco Palmas, tem se mostrado suficiente desde 2009 até os dias atuais. Ele foi sendo lançado aos poucos na comunidade por meio de alguns mecanismos. Entre estes estão os empréstimos concedidos para consumo, realizados em Palmas (até 600 Palmas). Outra forma de lançar as moedas sociais na comunidade é por meio do pagamento de parte da remuneração dos membros do banco em Palmas ( $10 \%$ da remuneração). Algumas entidades parceiras locais também podem oferecer parte da remuneração em Palmas. Além disso, qualquer pessoa pode trocar real por Palmas nos caixas do banco comunitário para consumir na comunidade estimulada pelo desconto de $5 \%$ nas compras com a moeda social oferecido por alguns comerciantes.

Ao longo de 5 anos (2005 a 2009), houve notável aumento do volume de Palmas lançado na comunidade. Para se ter uma ideia, apenas sob a forma de empréstimo, foi lançado um volume de 10 mil Palmas em 2006, passando a 25 mil em 2008 e 
alcançando 36 mil em 2009 (INSTITUTO BANCO PALMAS, 2012). Entre os motivos que levaram os moradores ao uso da nova moeda, destacou-se a simples preocupação em ajudar o comércio do bairro, conforme pesquisa de Silva Júnior (2008). Os resultados desta pesquisa de avaliação demonstraram os efeitos positivos dos processos de sensibilização sobre o uso da moeda empreendidos pelo Banco Palmas, bem como seu alto grau de legitimidade (SILVA JUNIOR, 2008). Naquele momento, tanto os comerciantes como os moradores tinham clareza do papel da moeda social e dos seus potenciais efeitos positivos para o território.

Esta primeira avaliação considerou um universo de 253 respondentes entre os quais $58 \%$ afirmaram usar ou ter usado a moeda social Palmas em 2008. No entanto, pesquisas mais recentes começaram a indicar um volume menor de usuários e de moeda social em circulação (MEYER, 2012). É preciso observar que em nenhuma destas pesquisas buscou-se compreender mais detalhadamente o circuito monetário e os motivos pelos quais ele estava se esvaziando. Diante disso, propõe-se, neste estudo, compreender melhor a situação que se delineava no Conjunto Palmeira em relação ao uso da sua nacionalmente conhecida moeda social.

\section{O PARADOXO DA MOEDA PALMAS: O PROGRESSIVO DESUSO VERSUS O AUMENTO DO CONSUMO LOCAL}

Meyer (2012) efetuou uma análise com base nas entradas e saídas de moedas sociais no Banco Palmas no período de janeiro a outubro de 2011 e identificou que o pagamento de parte do salário dos funcionários era o principal meio de lançar a Palmas no território, responsável por $73 \%$ das emissões do período analisado. 0 crédito para consumo, com uma média de 12 liberações mensais, respondia apenas por $27 \%$ do volume lançado. Ao analisar os retornos da moeda social para o Banco Palmas, Meyer (2012) observa haver concentração do volume de Palmas no único posto de gasolina do bairro ( $81 \%$ do volume que retornou no período). $\mathrm{O}$ volume de Palmas recebido pelos empreendimentos locais de maior porte era em grande parte usado para abastecer automóveis e motos (notadamente as de serviço de entrega em domicílio), o que encurtava sobremaneira o circuito monetário.

Para Meyer (2012, p. 101), o fato de os funcionários se apropriarem de $85 \%$ das emissões (73\% sob a forma de salário e $12 \%$ sob a forma de crédito para consumo) e o fato de o volume de moeda social se concentrar no posto de gasolina do bairro restringem a apropriação comunitária da moeda: "A apropriação é de fato concentrada nas mãos de alguns grupos territoriais (pessoal do Banco Palmas, posto de gasolina) que impedem as Palmas de serem usadas por um número importante de habitantes no bairro". O autor argumenta que esta situação indica uma fraca viabilidade social da moeda.

No entanto, aqui que se entende que a pouca apropriação da moeda pelos moradores atualmente tem outros motivos. Tendo em vista que o Banco Palmas possui lastro e um fundo de crédito para consumo considerável (cerca de 200 mil reais), o problema não é de apropriação por parte de um pequeno grupo, mas de não uso ou desuso por parte dos moradores e empreendimentos locais. Além disso, o próprio Meyer (2012) identificou ser baixa a troca direta de real por Palmas pelos moradores. Ou seja, se existe lastro suficiente para fazer circular um volume de cerca de 200 mil Palmas na comunidade, por que os moradores não a usam? Se há duas formas de emissão de Palmas diretamete pelos moradores - a troca direta do real por Palmas e o acesso ao crédito para consumo em Palmas -, significa que eles têm deixado de acessar a Palmas por estas vias e, consequentemente, ela não tem chegado ao mercado local para uso no consumo.

Durante as investigações nesta pesquisa, situações relativamente contraditórias puderam ser identificadas. Uma delas diz respeito a um aumento do número de empreendimentos cadastrados como recebedores de moedas sociais ao mesmo tempo que, a partir de 2010, nota-se uma diminuição da demanda por crédito para consumo. Para se ter uma ideia, são realizados em média doze liberações de crédito para consumo por mês, enquanto 392 demandas e liberações de crédito produtivo em reais ocorrem no mesmo período de tempo. Ao mesmo tempo, o consumo no bairro tem se mantido elevado, indicando, obviamente, que os moradores têm acesso e usam a moeda nacional no consumo. E o que estaria levando as pessoas a não mais usarem a moeda social? Esses questionamentonos levaram a buscar compreender de forma mais detalhada o circuito da Palmas no Conjunto Palmeira com o intuito de (re)significar seu sentido e seus usos no território. As análises das entradas e saídas oferecem indícios, mas apontam para a importância de se entender mais aprofundadamente o caso. 


\section{As especificidades dos atores e das relações socioeconômicas no circuito monetário alternativo}

No período de imersão etnográfica no Banco Palmas, questionou-se o gerente de um dos principais mercadinhos do bairro sobre a possibilidade de se retirar a moeda social de circulação. A resposta foi que uma medida dessa natureza prejudicaria o negócio. No entanto, ao analisar o volume de compras com Palmas neste mesmo mercadinho, identificou-se que este era baixo e que não afetaria as vendas do empreendimento. Então, por que a resistência em interromper a circulação da Palmas?

A redução no uso e a resistência à sua interrupção permeiam todo o circuito da moeda no bairro. Mas o enfraquecimento significativo do fluxo de moedas sociais, tanto em termos de volume, quanto em termos de frequência, é uma realidade. Essa constatação, por meio de entrevistas e conversas no território, apontou para a necessidade de se compreender melhor o circuito monetário construído pelo Banco Palmas, suas especificidades em termos de atores envolvidos e as relações entre eles. Sendo assim, em novembro de 2013, foi feito um mapeamento do circuito completo, que identificou os atores envolvidos, as relações e os sentidos do fluxo monetário entre eles. Esse mapeamento possibilitou a elaboração gráfica em forma de redes, a indicação das alterações no circuito e algumas inferências sobre sua tendência.

A elaboração gráfica do circuito da Palmas no território seguiu a legenda apresentada no Quadro 1 para todas as redes apresentadas aqui:

\section{Quadro 1}

Legenda para leitura das redes representativas do circuito do uso da Palmas no Conjunto Palmeira

\begin{tabular}{|l|l|l|l|}
\hline & Empreendimentos locais que usam Palmas & & Funcionários do Banco Palmas \\
\hline & Empreendimentos locais que deixaram de aceitar Palmas & Prossumidores \\
\hline & Empreendimentos locais que não aceitam Palmas & Banco Palmas \\
\hline & Empreendimentos locais que gostariam de aceitar Palmas & $\rightarrow$ & Relações existentes \\
\hline & Moradores do Conjunto Palmeira e de bairros vizinhos & $\longrightarrow$ & Relações passadas ou enfraquecidas \\
\hline
\end{tabular}

Fonte: Elaboração própria.

O sentido das setas indica o sentido do fluxo da moeda social. Dos 240 empreendimentos cadastrados no Banco Palmas como receptores da Palmas, foram mapeados 46 empreendimentos que ainda existem e aceitam a moeda. Detectou-se que cerca de 100 não existiam mais, haviam trocado de proprietário ou estavam fechados. Além destes, 12 empreendimentos não aceitavam mais a moeda principalmente por dois motivos: por não estarem mais recebendo pagamentos em Palmas há muito tempo e porque o volume recebido era muito baixo. 0 mapeamento possibilitou também identificar 11 empreendimentos que não estavam cadastrados, mas aceitavam e usavam a moeda social, e 7 empreendimentos que não a usavam, mas tinham interesse em fazê-lo. Estes últimos indicaram não conhecer bem o funcionamento da moeda, pois seria necessário uma maior divulgação.

Além de realizado o cadastro de empreendimentos locais, foram entrevistados 10 produtores e consumidores locais tomadores de empréstimo produtivo e de consumo, que aceitam e usam Palmas. Tais atores foram denominados de prossumidores. Além disso, também se fez contato com uma associação cultural. Os prossumidores e a associação foram selecionados por meio dos registros de crédito do Banco Palmas com o intuito de diversificar os tipos de atores do circuito. Faz parte, ainda, da rede mapeada o próprio Banco Palmas como emissor e gestor da moeda. 
Ainda entre os atores que compõem o circuito, quatro deles representam grupos maiores de atores do território, tendo em vista as dificuldades metodológicas de identificar cada um deles. Estes atores são os moradores em geral, que foram caracterizados por meio da aplicação de 97 questionários específicos; os moradores de bairros vizinhos - citados em algumas entrevistas -; e os próprios funcionários do Banco Palmas, por receberem parte do salário em moeda social e serem um tipo específico de ator para a emissão de moedas. Estiveram, ainda, representados na rede os demais empreendimentos do território que não estão cadastrados e que não aceitam a moeda. Seis deles foram entrevistados tendo por objetivo identificar os motivos e a percepção sobre a moeda social no território. Por fim, mais 7 empreendimentos compõem a rede por terem sido citados como receptores ou recebedores de moedas, mas seus representantes não puderam ser entrevistados pelos pesquisadores em campo (ou por tais estabelecimentos não existirem mais ou por não constarem no cadastro, o que inviabilizou encontrá-los sem os respectivos endereços nos dados).

Os atores individuais mapeados juntamente com os grupos de atores representados formam uma rede de 99 nós e um emaranhado de relações socioeconômicas e de troca. Alguns desses atores, notadamente o Banco Palmas e alguns empreendimentos locais, assumem o papel preponderante no circuito. Esses atores são representados no esquema gráfico da rede por símbolos maiores, com tamanho proporcional ao número de relações direcionadas ao ator (indegree). Essa é uma medida de centralidade na análise de redes sociais e que, neste caso, indica os atores que se encontram no sentido do fluxo da moeda. Ou seja, são os principais recebedores de Palmas no território.

Na Figura 1, pode-se identificar dois grandes grupos: os empreendimentos conectados à rede e aqueles desconectados dela. Destes últimos fazem parte aqueles empreendimentos que deixaram de aceitar a moeda (representados em preto); aqueles que a aceitam mas nunca a receberam (representados em azul); e aqueles que não a aceitam por desconhecimento, mas gostariam de aceitá-la (representados em rosa). Entre esses atores desconectados, foi possível identificar ainda um prossumidor (representado por círculo verde) que deixou de aceitar a moeda por acreditar que ela não circulava mais. 


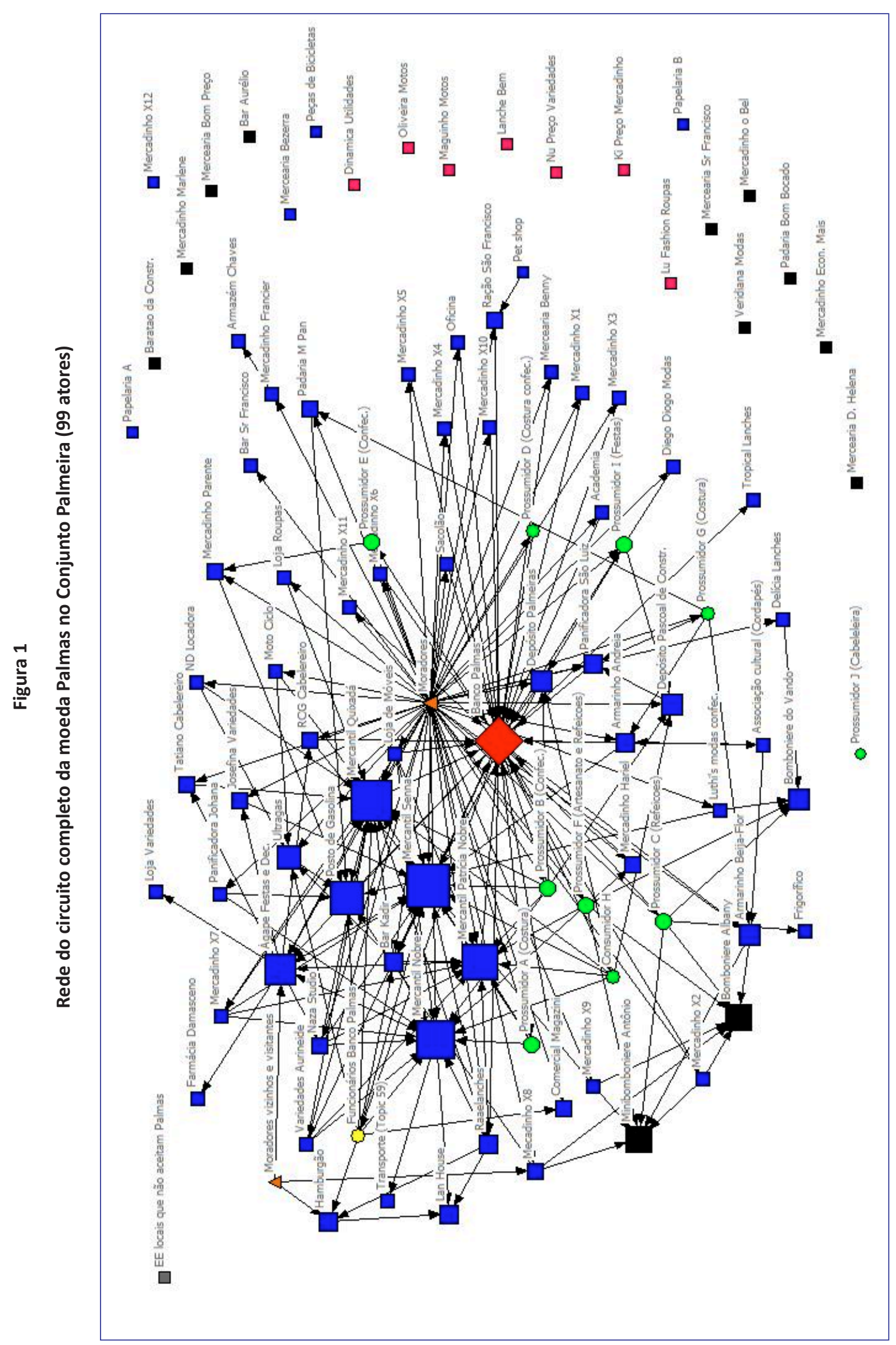

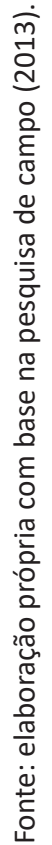


No conjunto da rede foram identificados sete atores de maior centralidade: o próprio Banco Palmas (em vermelho) como ator central receptor e emissor da moeda; quatro mercadinhos locais que vendem itens de primeira necessidade; o posto de gasolina do bairro e uma loja de festas e decoração. Além desses, duas bombonieres também se mostraram importantes ao longo da história do circuito, embora no momento da entrevista tenha-se obtido a informação de que não aceitavam mais a moeda (por isso representadas em preto).

Notamos o papel preponderante do Banco Palmas como receptor da moeda social e não tanto como emissor. Isso pode ser explicado pela notável diminuição do volume de crédito para consumo e pela interrupção do pagamento de parte dos salários ( $10 \%$ do salário) dos seus funcionários em moeda social. No entanto, ainda é esta modalidade de crédito o principal "motor" da rede, tendo em vista que é o conjunto dos moradores do bairro que direciona o maior fluxo de moeda para os empreendimentos locais.

Essa relação estreita entre crédito para consumo e fluxo de moeda social fica mais evidente se forem considerados no circuito apenas os empreendimentos locais e excluídos o Banco Palmas e seus funcionários, os moradores, vizinhos e prossumidores; ou seja, os principais tomadores de crédito para consumo. Na Figura 2 nota-se que, apesar de ainda restar um circuito monetário notadamente em uma "ilha" de empreendimentos na qual os mercadinhos maiores assumem a centralidade do fluxo, este circuito é sensivelmente restrito. À primeira vista, essa "ilha" de circulação da moeda entre os empreendimentos é relativamente independente do Banco Palmas; os mercadinhos locais maiores assumem o papel de principais receptores da moeda. No entanto, é possível perceber que a não alimentação do fluxo pelos moradores e prossumidores tende a enfraquecê-lo.

Da perspectiva neste estudo seria possível manter certo nível de circulação entre esses empreendimentos, tendo em vista que há diversidade entre os 14 atores dessa "ilha" de circulação da moeda. Nota-se que ela é formada por cinco mercadinhos (que comercializam as mesmas mercadorias), um bar, uma loja de móveis, duas lojas de variedades, dois salões de beleza, um posto de gasolina, uma distribuidora de gás de cozinha, uma panificadora e uma loja de festas e decoração. No entanto, o próprio posto de gasolina é um ponto de "estrangulamento", na medida em que é o único no território e não realiza compras com outros empreendimentos do circuito. Isso corrobora os achados de Meyer (2012) quando, embora de modo simplificado, identificou o maior volume de moeda social proveniente do posto de gasolina para ser trocado por reais no Banco Palmas. 


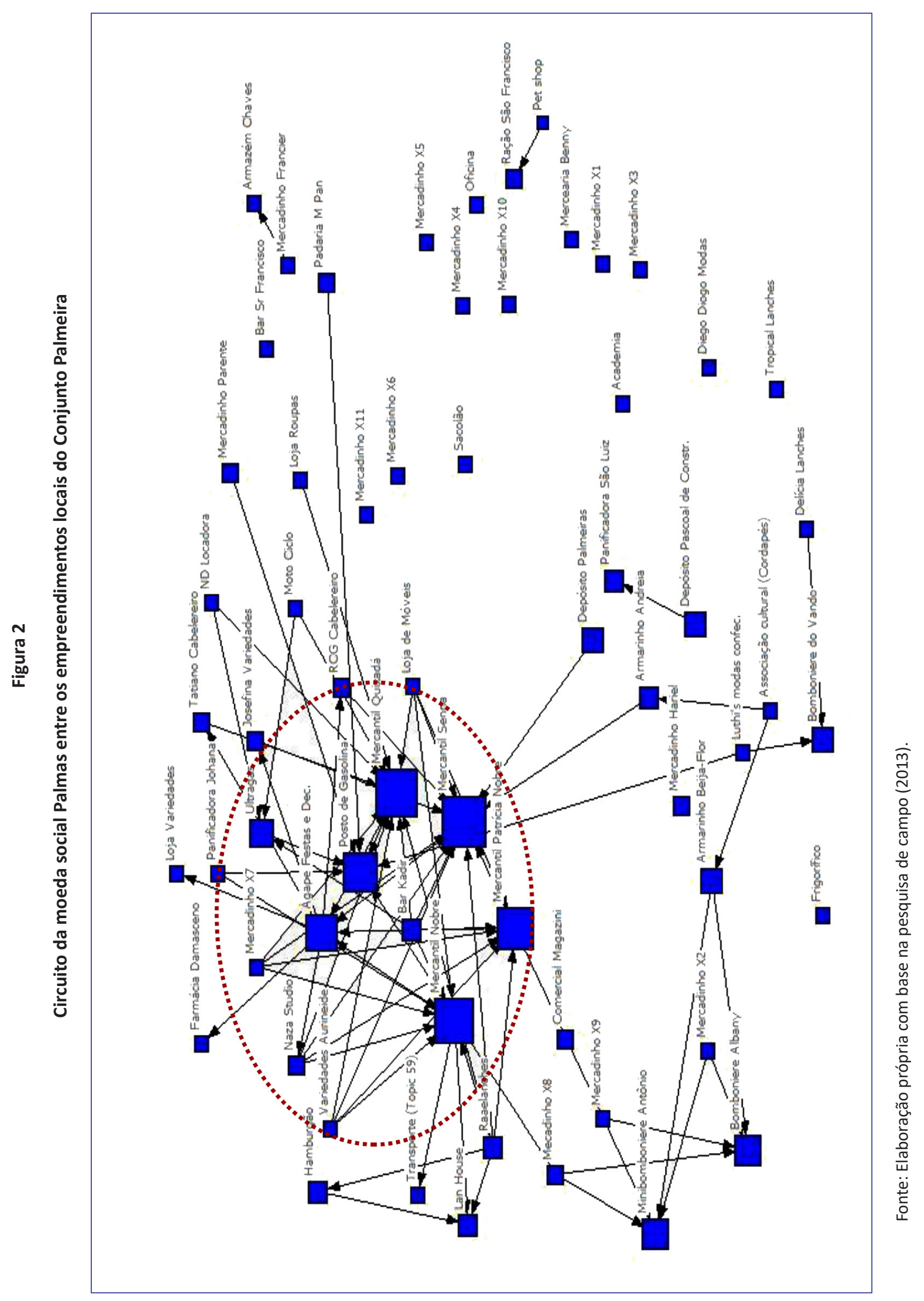


As informações qualitativas levantadas em campo permitiram identificar o progressivo enfraquecimento do fluxo da moeda social no território. Por exemplo, de importantes empreendimentos desta rede, como o posto de gasolina e duas bombonieres, obteve-se a informação de que não mais recebiam a moeda há alguns meses. Por meio desse tipo de informação, obtido com quase todos os atores da rede (poucos não responderam às questões abertas), foi possível retrabalhar a rede de 99 atores e compreender seu enfraquecimento de uma maneira progressiva.

A diminuição do uso da Palmas no território e a desconexão de certo número de atores (e vice-versa) têm levado a um notável enfraquecimento do fluxo da moeda e das relações (frequência e volume de moeda) entre os diferentes atores. Na Figura 3 , pode-se identificar o emaranhado de relações que deixaram de ser realizadas em moeda social (representadas na cor vermeIha). Em média, a maioria dos entrevistados afirmou não receber a moeda social há dois anos. No entanto, em alguns casos, as relações de uso da moeda não ocorrem há mais de cinco anos. Os comentários mais comuns dos comerciantes foram: "Faz tempo que ninguém compra com Palmas"; "Não recebi mais a moeda"; "Não chegou mais Palmas, e eu só recebi uma vez"; "Eu aceito, mas nunca ninguém veio comprar com Palmas"; "Há anos não recebo mais, desde 2010"; "Há alguns anos não as recebo, nem sabia que ainda circulavam"; "Há mais de anos que não recebo, a moeda circula mais no centro"; "Não recebo há anos, já nem ouço mais falar"; "Já recebi muitas Palmas no passado, mas hoje é praticamente nada"; "A circulação diminuiu muito e parou desde o assalto ao Banco Palmas".

Nos depoimentos, nota-se que a pouca circulação da moeda está relacionada menos com a não aceitação dos comerciantes e mais com o não uso dos moradores no comércio local. Nota-se que certa progressividade no desuso das Palmas, na medida em que as pessoas apontam que nos últimos anos não a têm recebido ou mesmo haja menção a ela. 


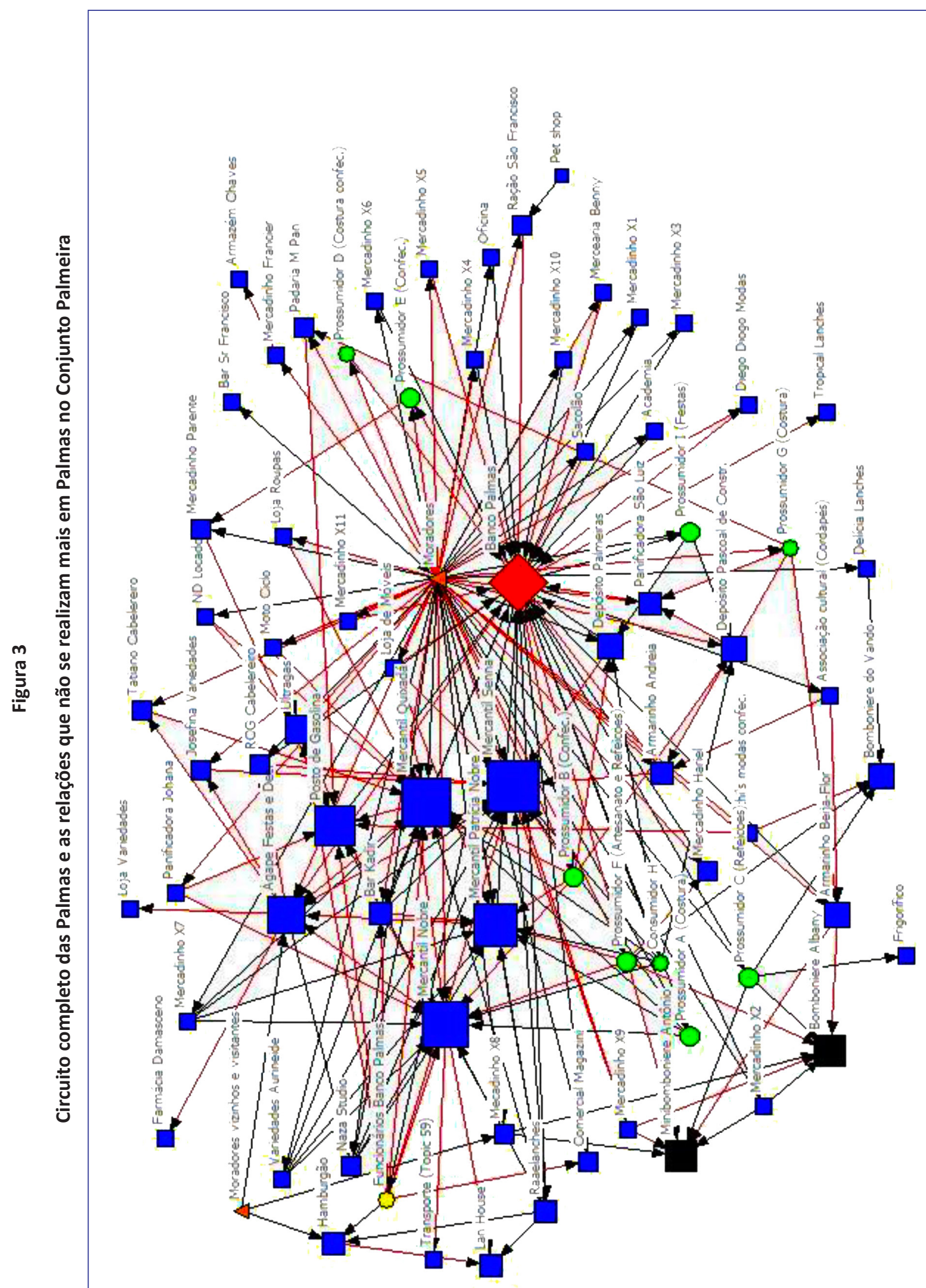

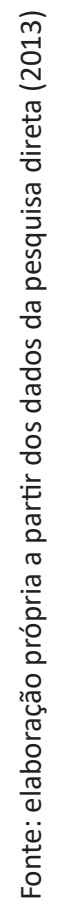


Associado a isso, e conforme entrevistas em campo, o Banco Palmas diminui os esforços na divulgação da moeda no bairro. Isso se configura como um fator importante, tendo em vista que a dinâmica de chegada e saída de pessoas no território tem sido intensa nos últimos anos, notadamente após sua urbanização. Além de receber com frequência novos moradores, são consideráveis o número e a velocidade com que novos empreendimentos são criados ou deixam de existir no bairro. Dos 240 empreendimentos cadastrados no Banco Palmas como recebedores de Palmas, muitos não existiam mais em novembro de 2013. Tais aspectos territoriais exigem do Banco Palmas um programa de sensibilização constante sobre a importância do consumo no bairro tendo como instrumento pedagógico sua moeda social. A Figura 3 representa, então, um circuito que dá sinais de enfraquecimento desde os últimos cinco anos.

Quando são retiradas do circuito essas relações de troca que não acontecem mais em moeda social, há aproximação de um circuito denominado circuito "atual" da Palmas no Conjunto Palmeira. Neste circuito, 31 atores deixaram de fazer parte da rede somando-se aos 24 atores não mais conectados anteriormente. Assim, de uma rede com 99 atores, progressivamente o circuito se resume a 43 . Sobre esta base de 43 atores, novas configurações puderam ser construídas por meio das informações qualitativas.

\section{O ATUAL CIRCUITO DA MOEDA PALMAS: O PARADOXO DA RELAÇÃO ENTRE UM FRACO FLUXO MONETÁRIO EM UMA FORTE REDE DE ACEITAÇÃO}

Apesar das dificuldades de calcular essa massa monetária que efetivamente flui entre os atores do circuito, pôde-se identificar que ela se encontra consideravelmente reduzida. As dificuldades de identificar este volume de moeda provêm do fato de grande parte dos atores da rede não se lembrar da média de trocas justamente por elas não mais acontecerem sistematicamente. Todos enfatizaram que o volume é baixo.

Entre os maiores empreendimentos (notadamente os quatro mercadinhos maiores), os valores são mais expressivos e variam de 500 a 2.500 Palmas mensais. Os valores dos demais empreendimentos e prossumidores variam de 7 a 2.000 Palmas. $O$ valor médio mensal do conjunto de 43 empreendimentos locais e prossumidores é de 336,42 Palmas, o que equivale a uma massa monetária em circulação de 13.457 Palmas. Identificou-se, ainda, que, desse total, 6.500 Palmas ou seja, quase a metade, é direcionada aos quatro mercadinhos locais de maior porte. Apesar de não ter feito parte da pesquisa (houve recusa), o posto de gasolina se configurou como um dos atores receptores de parte desse fluxo direcionado aos mercadinhos - troca o volume diretamente no Banco Palmas no final do mês. Assim, de fato, de 40 mil Palmas que o Banco Palmas emitiu ao longo desses anos de criação e implementação da moeda social, hoje cerca de 27 mil restam disponíveis, mas reservadas em seu caixa.

O mapeamento do circuito da Palmas permitiu, em certa medida, qualificar as relações por meio do uso da moeda social em questionamento aos entrevistados sobre a frequência de seu uso e o tipo de relação que cada um dos atores mantinha ou havia construído por meio dele. Com base nestas informações, é possível reconstruir graficamente o circuito da Figura 3 e apontar novos fluxos que tendem a desaparecer por serem raros. Retirando-se do circuito essas relações raras de uso de moeda social, pôde-se construir a rede da Figura 4. Nela, restam 27 atores; 6 relações foram destacadas em cor vermelha, indicadas como sensivelmente enfraquecidas pelos principais atores da rede - notadamente os dois mercadinhos locais que ainda recebem e usam um certo volume de moedas sociais (embora baixo e não muito frequente).

Na Figura 4, a relação destacada em vermelho entre o Banco Palmas e os moradores representa a diminuição na demanda por crédito para consumo que é oferecido em moeda social pelo Banco Palmas. Essa redução no volume de crédito acarrreta redução também no número de relações entre os moradores e os dois empreendimentos locais maiores que restaram no circuito. A tendência, então, é de que também diminua o fluxo em direção ao posto de gasolina e mesmo ao Banco Palmas para pagamento de contas ou troca direta por esses empreendimentos.

Paralelamente à diminuição da demanda e, consequentemente, da oferta de crédito para consumo no bairro, a interrupção do pagamento de parte dos salários dos funcionários do Banco Palmas em moeda social também influenciou sobremaneira a diminuição do volume e da frequência do uso da moeda no território. Esse conjunto de fatores foi apontado por vários empreendimentos como importantes dentro do circuito monetário de uso da moeda social. 
Diante das análises até aqui empreendidas, o circuito monetário construído pelo Banco Palmas ao longo desses anos de uso de moeda social não tem se fragilizado por conta da não aceitação dos empreendimentos locais. O que se identificou é que se formou no Conjunto Palmeira uma rede de aceitação da moeda significativamente extensa e que oferece legitimidade à Palmas e ao seu emissor. Configura-se atualmente no bairro uma forte rede de aceitação da moeda, mas com fluxo cada vez mais enfraquecido. Seria outro ou parte do mesmo paradoxo? O que se entende é que, nesse momento, os moradores do bairro são os atores mais relevantes para a reconstrução do circuito. Se no Banco Palmas as moedas estão disponíveis sob a forma de crédito para consumo ou troca direta (tendo em vista que não há problema de insuficiência de lastro no banco), depende dos habitantes o interesse em acessá-las. O que ocorre é que eles não têm acessado a moeda social apesar de reconhecer a importância de consumir no bairro. Assim, o consumo tem sido realizado em real. Além disso, se a demanda por crédito para consumo diminuiu, como já demonstrado, significa que o acesso à moeda nacional está facilitado.

Buscou-se, então, entender por que os moradores não mais têm se interessado em acessar e usar a moeda social. Dos 97 moradores entrevistados no bairro durante a pesquisa (sete moram em bairros vizinhos e 90 no Conjunto Palmeira), 87,8\% (79 moradores) vivem nele há mais de cinco anos e quase a totalidade deles (cerca de $90 \%$ dos respondentes) conhece a moeda social Palmas. Entre todos os entrevistados, apenas 16 já a usaram e, destes, apenas três declararam ainda usá-la. Isso comprova o desuso da moeda social por parte dos moradores, ao mesmo tempo que explica o fato de grande parte dos empreendimentos que compõem o circuito monetário não receber pagamento em moeda social com frequência.

Na Figura 5, foi possível pôr em foco o papel dos moradores no processo de desuso da moeda social, identificando as relações de uso de moeda que existem mas que são raras, e reconfigurando o circuito.

Figura 4

Circuito atual da moeda Palmas no Conjunto Palmeira diante de novos sinais de enfraquecimento (27 atores)

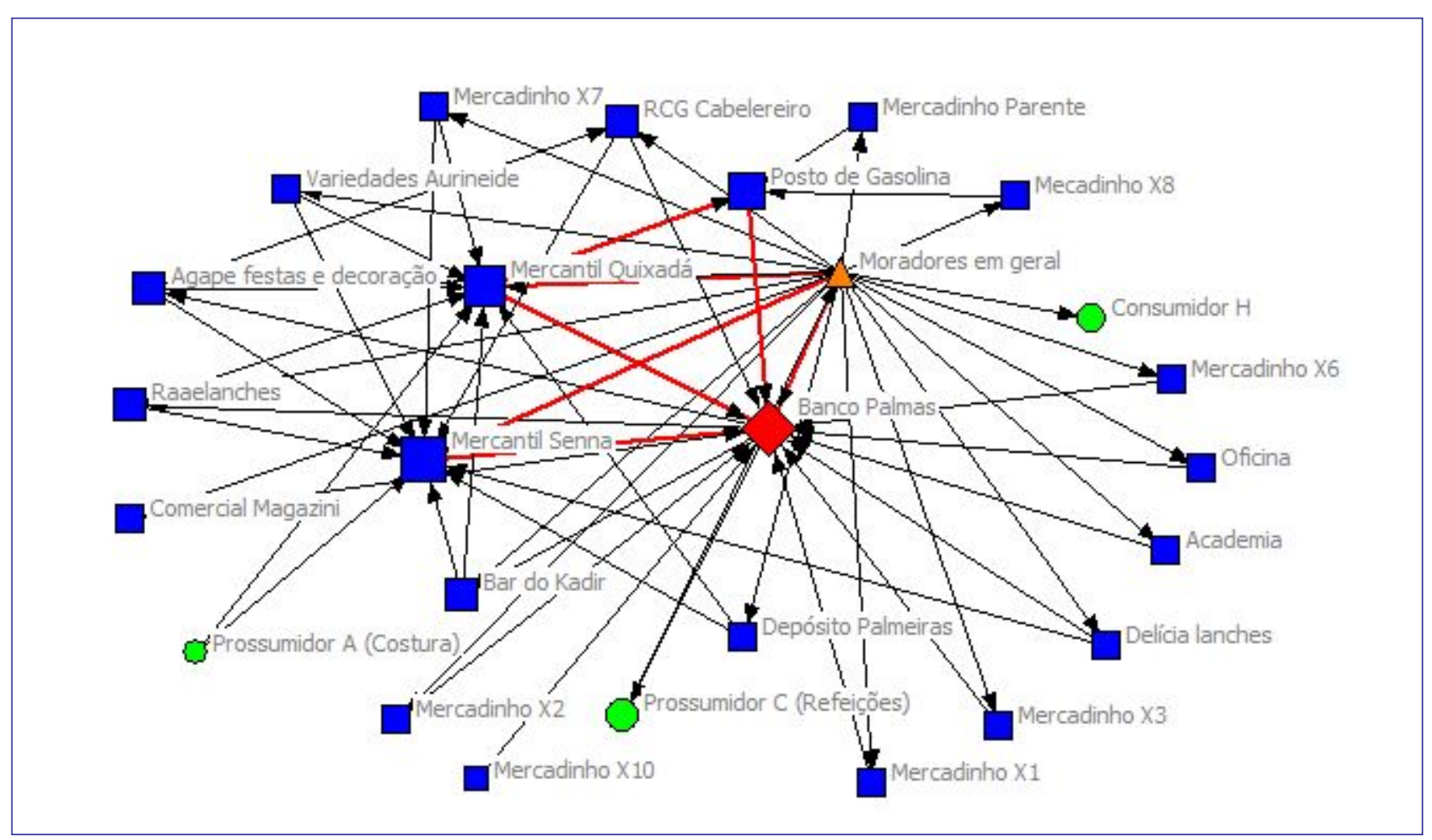

Fonte: elaboração própria com base na pesquisa de campo (2013). 


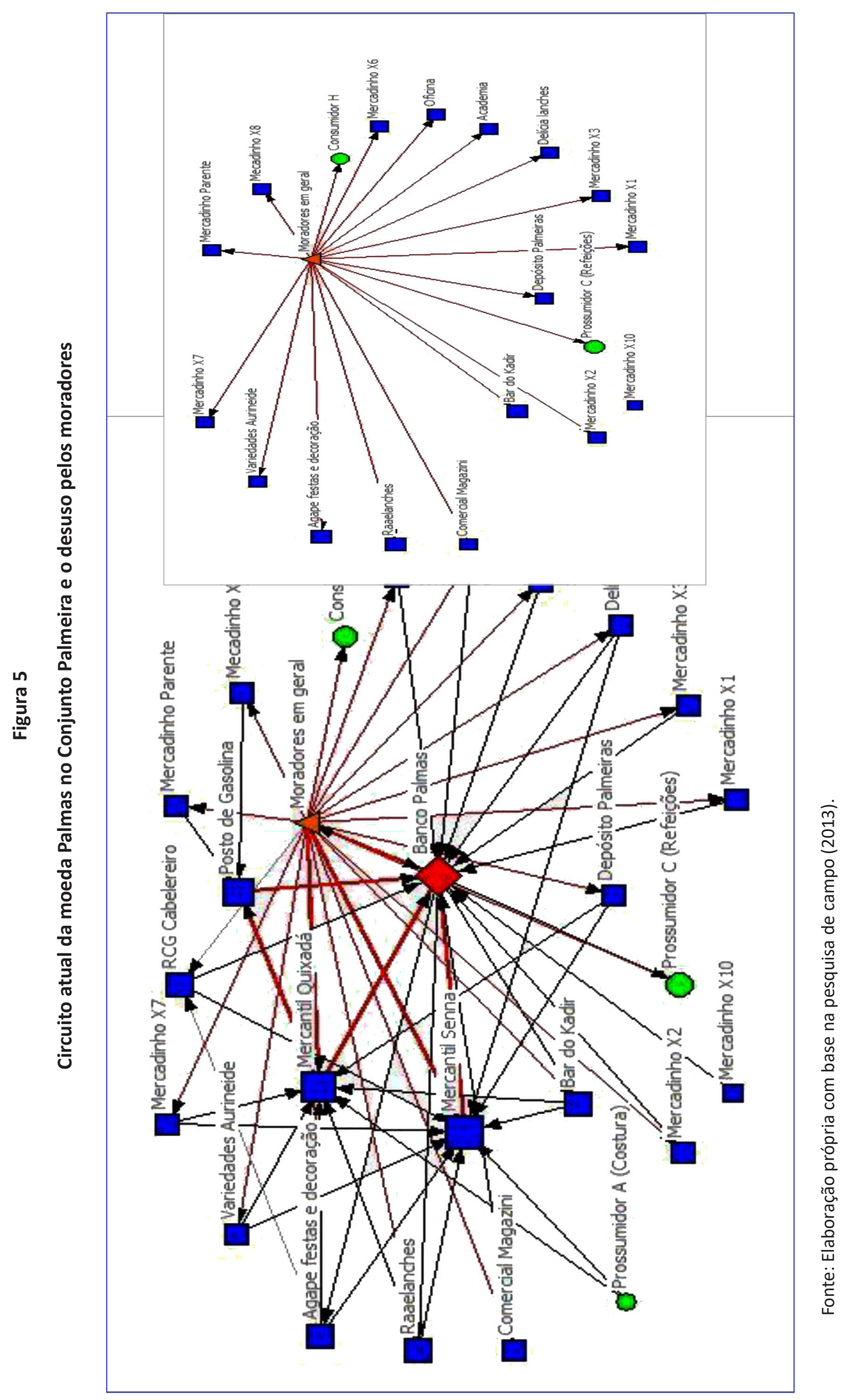


A maioria dos moradores entrevistados respondeu não ter interesse em usar a moeda (38\%) ou não ter sentido necessidade de usá-la (17,7\%). Alguns mencionaram não ter tido oportunidade (8,9\%), o que pode ser explicado pelo próprio enfraquecimento do circuito. Configura-se, assim, um movimento de duplo sentido: quanto mais o circuito enfraquece em termos de volume e de frequência de uso, menor a chance de um morador recebê-la na forma de troco, por exemplo. Ao mesmo tempo, quanto menos o morador usa, mais fraco se configura o circuito.

A maioria dos entrevistados comentou não ter interesse ou não ter sentido necessidade de utilizar a moeda. No entanto, considerando que haveria interesse caso houvesse necessidade, e tendo em vista a disponibilidade de moeda no Banco Palmas, infere-se que a maioria dos moradores não tem sentido necessidade de usá-la. Isso está associado, pelo menos em parte, à baixa demanda pelo crédito de consumo. Ou seja, há menos urgência por parte dos moradores em acessar os recursos desta linha de crédito. Desse modo, pode-se inferir que há mais liquidez em moeda nacional no território.

Entrevistas e a própria vivência etnográfica no território mostraram que parte dessa liquidez provém de mecanismos de inclusão financeira que o próprio Banco Palmas disponibilizou para a população local. $\mathrm{O}$ acesso à abertura de contas e ao cartão de crédito no correspondente bancário da Caixa Econômica que o Banco Palmas opera é aqui entendido como o principal mecanismo de acesso a recurso imediato. Agora muitos moradores, em vez de solicitarem o crédito para consumo de itens de urgência, fazem-no com o cartão de crédito, que também possibilita pagamento posterior da dívida. Pode-se inferir também, como mais um importante fator influenciador, que o acesso ao recurso do programa Bolsa Família por grande parte dos moradores diminui a demanda pelo crédito para consumo e contribui para o aumento da liquidez no bairro.

Associadas entre si, essas variáveis relativas ao aumento da renda dos moradores; ao acesso ao sistema financeiro tradicional (notadamente abertura de conta e cartão de crédito); à interrupção pelo Banco Palmas do pagamento de parte dos salários dos seus funcionários em moeda social associadas têm - ao longo dos últimos cinco anos - provocado o enfraquecimento do fluxo de moeda social na rede de aceitação construída até então pelo Banco Palmas. Tal rede permanece legítima e consideravelmente ampla, como visto na rede de empreendimentos que representa o circuito. Configura, assim, o paradoxo da relação entre fraco fluxo monetário (baixa frequência e volume) numa forte rede de aceitação (legitimidade da moeda entre os empreendimentos e moradores).

Inferências acerca do futuro do uso da moeda Palmas no território poderiam ser seguramente feitas. Parece óbvio que o circuito da Palmas no território tende a desaparecer ou, ainda, que o Banco Palmas pode capturar as moedas sociais facilmente e retirá-las de circulação definitivamente, tendo em vista os custos que envolvem sua manutenção. Teriam, então, as moedas sociais um caráter transitório e de urgência? A diminuição do volume de moeda e da frequência das trocas leva mesmo à interrupção efetiva do circuito? Quais outros dispositivos monetários complementares podem ser criados no mesmo território? A preocupação com a questão do consumo local e a manutenção das poupanças e da riqueza no território é central nas ações do Banco Palmas e sua capacidade e inventividade tornam imprecisa qualquer inferência.

Apoiado por sua rede de parceiros fora e dentro do territorio, o Banco Palmas tem buscado requalificar o uso da Palmas construindo um circuito eletrônico de uso da moeda e de acesso ao crédito. Projetos como a moeda Palminhas (lançado em 2013), direcionados às crianças e a futuras gerações do território, bem como o e-dinheiro, lançado em 2015, são exemplos de ações em torno da moeda social que inovam na forma como são usadas.

Encerrada a descrição e a apresentação do paradoxo encontrado no uso da moeda social Palmas, passa-se, na próxima sessão, a reflexões baseadas na teoria da dádiva e nos conceitos-chave discutidos no referencial teórico.

\section{REFLEXÕES COM BASE NA EXPERIÊNCIA DO (DES)USO DA PALMAS: A DÁDIVA COMO “PANO DE FUNDO" E A MOEDA SOCIAL ENQUANTO “FILOSOFIA"}

A moeda social não é um instrumento, um pedaço de papel, ela é uma filosofia. (Entrevista, Joaquim de Melo Neto, nov. 2013).

$\mathrm{O}$ uso de moedas sociais pelos $\mathrm{BCD}$ indica que, ao lado do mercado de bens e serviços e dos mecanismos de redistribuição, existe uma série de experiências que se baseiam em laços sociais e relações de confiança. No caso da experiência do Banco Palmas, ficou evidente que a instituição conseguiu construir uma rede de aceitação da moeda no território baseada na relação 
de confiança estabelecida ao longo dos anos da sua atuação. Sendo assim, a confiança parte menos do objeto em si (papel moeda) e mais da legitimidade do banco comunitário e de todos os instrumentos ou mecanismos que ele cria (e imprime a marca "Palmas") com o intuito de desenvolver o local.

Nesta análise, a tríplice ação dar-receber-retribuir aparece como "pano de fundo" da atuação do Banco Palmas, tendo no uso de uma moeda social uma "filosofia da forma de atuar no território" (Entrevista, out. 2013). No entanto, no que diz respeito ao uso especifico da moeda por cada ator da rede ou circuito monetário criado, a satisfação dos interesses, notadamente econômicos, manifesta-se mais evidentemente do que os laços sociais criados como possíveis relações de amizade ou familiares. No mapeamento do circuito monetário e diante do esforço de qualificar as relações de troca que nele ocorrem, não foram encontrados indícios de que o uso da moeda cria ou reforça laços entre os atores. Para tanto, pesquisas que aprofundassem este aspecto seriam interessantes.

O estabelecimento de uma dívida, nas relações de troca analisadas pela antropologia da moeda, baseadas na teoria do dádiva, ocorre no intuito de estas relações serem mantidas, de estabelecer "[...] uma ligação durável entre grupos de indivíduos" (CAILLÉ, 1995; 2002a; GODBOUT, 1999; ROSPABÉ, 1995). Uma relação que nenhuma moeda pode apagar (ROSPABÉ, 1995). O que se percebe no caso da Palmas é que esta relação duradoura ocorre entre a rede de aceitação e o Banco Palmas.

A confiança, no entanto, permeia as relações entre o BCD e a comunidade. Sendo assim, o uso da moeda no território está intimamente relacionado ao papel do BCD: sua política, sua atuação e sua capacidade de sensibilização dos atores locais para a construção e o funcionamento de um circuito monetário local. Desse modo, o movimento entre as ações da tríplice ação dar-receber-retribuir estaria menos presente nas relações entre os atores da rede (indivíduos e empreendimentos) e mais evidente no conjunto de ações do BCD para com a comunidade e vice-versa. Como visto nas sessões anteriores, o desuso por parte dos moradores por "falta de interesse" (provalvemente um interesse utilitário) não foi capaz de desconstruir o circuito que permaneceu amplo na rede de aceitação. Os morados não usam mas aceitam, os empreendimentos não têm recebdido, mas aceitam. Segundo entendimento nesta pesquisa, há um sensível papel simbólico e polítco desempenhado pelo uso da moeda no território, mas não traduzido em termos de volume e frequência de uso. Para estes atores, basta saber que a moeda existe, que foi criada por eles e que pode ser acessada quando necessário.

Buscando mostrar a dinâmica do (des)uso da Palmas na tríplice ação dar-receber-retribuir da teoria da dádiva (conforme descrita em Caillé, 1995), compreende-se que a ação de dar, que gera expectativa, é empreendida pelo Banco Palmas ao atuar na comunidade facilitando a concessão de empréstimos, ofertando uma moeda social sobre a qual não incide juros, humanizando a cobrança e o processo de decisão sobre a concessão. O recebedor, tendo suas expectativas satisfeitas, retribui ao estabelecer uma relação de confiança com o BCD, acreditando nos seus mecanismos de desenvolvimento local, entre eles, a moeda social. $\mathrm{O}$ uso da moeda no circuito é, então, viabilizado por esta relação duradoura de confiança. No entanto, como visto anteriormente, o uso físico do papel moeda da Palmas está condicionado à satisfação de uma necessidade econômica, mas a existência da moeda não se limita a isso. Em outras palavras, a necessidade (ou interesse utilitário) leva os moradores a se dirigirem ao Banco Palmas e tomarem empréstimo para consumo. Porém a manutenção do uso da moeda no território é requerida pela carga simbólica, política ou mesmo institucional que nela está impressa. Ela representa o banco e o dinheiro exclusivos dos moradores, exclusivos do "bairro da economia solidária". Neste ponto, resgatam-se os sentidos ampliados da noção sobre a moeda discutidos por Blanc (1998), Théret (2008), Aglieta e Orléan (1992) e Rospabé (1995).

Esse sistema em movimento criado pela atuação do BCD no território assentado no uso de uma moeda social exprime também os paradoxos da teoria da dádiva apontados por Caillé (2002a). É possível entender o movimento entre o livre e o obrigatório, uma vez que a aceitação e o uso da moeda são livres, mas podem ser vistos como uma obrigação, sobretudo como resultado da sensibilização do Banco Palmas sobre a importância do uso da moeda para a manutenção da riqueza no bairro. Depoimentos de atores que usam a moeda, principalmente dos empreendimentos locais, revelam a expectativa positiva tanto para eles mesmos quanto para o bairro de modo geral. Afinal eles "estão fazendo sua parte" no processo (Entrevista, out. 2013).

O movimento entre o desinteresse e o interesse também se evidencia em meio à rede de aceitação da moeda social já construída. $O$ desinteresse se manifesta de modo menos evidente, mas pode ser percebido pela ideia de ser parte do "bairro que tem uma moeda própria” (Entrevista, jan. 2012), cujas imagens externa e interna construídas em torno da Palmas estimulam tanto o uso quanto sua aceitação. Além disso, a aceitação existe mesmo diante do baixo volume recebido por parte de alguns 
empreendimentos, ou seja, mesmo não tendo qualquer influência sobre o aumento das suas receitas. Já o movimento para o uso interessado, conforme explicitado, é mais notório entre os moradores.

Pode-se inferir que, nesse momento da rede de circulação da Palmas, sobressaem a liberdade do uso e o interesse por ele num movimento de aliança entre o Banco Palmas e a rede de aceitação da moeda social, que se estabelece com alguma incondicionalidade (CAILLÉ, 2002a). Esta incondicionalidade está intimamente ligada à legitimidade e ao reconhecimento do Banco Palmas no território. A relação que os moradores estabelecem com a instituição (a ponto de às vezes a confudir com a moeda social Palmas) evidencia também a obrigação (como uma espécie de norma social) e o desinteresse (ou interesse pelo outro). Assim, a lógica da dádiva ajuda a esclarecer a prática do uso da moeda social pelos BCDs. Porém, o uso da moeda também está atrelado aos aspectos territoriais que podem ser determinantes na construção do circuito monetário local. Por exemplo, a mobilidade das pessoas no território e a diversidade de empreendimentos locais influenciam no tamanho e na fluidez do fluxo de moeda social e na sua aceitação por parte dos moradores.

O "pano de frente" da prática dos BCDs e do uso da moeda social é a relação BCD-território-moeda. Na prática dos BCDs, o território exerce papel central e a moeda social serve exclusivamente ao território. 0 processo de criação da moeda e sua gestão representam a "soberania do território" em contraponto tanto à soberania estatal, que exerce o direito exclusivo de criar moeda, quanto à soberania mercantil, que reduz a moeda à função de meio de troca. O "valor" da Palmas está estrelado não apenas ao seu lastro com o real, mas ao símbolo do território impresso nas cédulas, que traduz a história do lugar e a confiança depositada na instituição emissora, o Banco Palmas. Nesse ponto, as moedas sociais podem ser entendidas como fato social total, como expressa Théret (2008), agregando os sentidos simbólico, econômico e o político.

Por fim, a reflexão que se delineia aqui é no sentido de haver uma filosofia do uso das moedas sociais (tendo a dádiva como fenômeno) como pano de fundo da prática do BCD. Isso se dá, portanto, em um nível de cunho mais metodológico e ideológico. À frente, em um nível prático e concreto (o que se denomina aqui de "pano de frente"), fica o verdadeiro intento de mudar o território, num processo em que a circunscrição do uso de uma moeda e a manutenção da riqueza no lugar são fundamentais.

Em resumo, pode-se concluir que a complexidade da moeda social Palmas, traduzida no paradoxo entre o utilitário e o não utilitário próprios de uma relação de dádiva, evidencia sua dupla face. De um lado, essa moeda cumpre uma função estritamente econômica de ser um meio de pagamento acessível aos que mais precisam, permitindo assim maior distribuição de riqueza na localidade como consequência do aumento de liquidez da economia local. Sua criação e uso visavam assim fomentar o consumo local. Por outro lado, a moeda social Palmas se constitui antes de tudo como um símbolo de legimidade da dinâmica local de mobilização de pessoas e instituições em prol do desenvolvimento do seu bairro consubstanciado na prática do Banco Palmas. A moeda torna-se um símbolo dessa prática e vetor de reconhecimento dela. As duas faces ou dimensões não se concebem separadamente. A função instrumental apenas se realiza se houver uma função simbólica cumprida, isto é, se houver legitimidade da prática empreendida no território. Assim se decifrou o "enigma" da diminuição da circulação da moeda e sua permanente legitimidade. Afinal de contas, seu papel instrumental já fora cumprido anteriormente e levou ao aumento do consumo local. Esse aumento se mantém graças a outros mecanismos de consumo que realizam esta mesma função, restando à moeda social cumprir seu papel simbólico e político. Ela é de certa forma um símbolo das relações de confiança permanentemente (re)construídas por meio das ações do Banco Palmas e pela preocupação dos seus moradores com seu próprio território. 


\section{REFERÊNCIAS}

AGLIETTA, M.; ORLÉAN, A. A violência da moeda. São Paulo: Brasiliense, 1990.

ANDION, C.; SERVA, M. A etnografia e os estudos organizacionais. In: GODOI, C. K.; BANDEIRA-DE-MELO, R.; SILVA, A. B. (Org.). Pesquisa qualitativa em estudos organizacionais: paradigmas, estratégias e métodos. São Paulo: Saraiva, 2006. 147-181 p.

BLANC, J. Las monnaies paralléles: èvaluation du phénomène et enjeux théoriques. Revue d'économie financière, n. 49, p. 81-102, set. 1998. Disponível em: <http://www.aef.asso.fr>. Acesso em: 01 jul. 2010.

BORGES, A. Banco Palmas como uma plataforma de desenvolvimento comunitário. In: MORAIS, L.; BORGES. A. Novos paradigmas de produção e consumo. São Paulo: Instituto Polis, 2011. 249-295 p.

BÚRIGO, F. L. Moeda social e circulação de riquezas na economia solidária. 2002. Disponível em: http://money.socioeco.org/documents/67pdf_Moeda.pdf. Acesso em: 29 ago. 2010.

CAILLÉ, Al. Prefácio. In: ROSPABÉ, P. La dette de la vie. Paris: Éditions La découverte/Mauss, 1995.

CAILLÉ, A. Antropologia do Dom: o terceiro paradigma. Petrópolis RJ: Vozes, 2002a. 7-139 p.

CAILLÉ, A. Dádiva e Associação. In: MARTINS, P. H. (Org.). A Dádiva entre os Modernos: discussão sobre os fundamentos e as regras do social. Petrópolis, RJ: Vozes, 2002b. 17-31 p.

FARE, M. Les condition monétaire d'un developpement local soutenable: des système d'échange complémentaire aux monnaies subsidiaire. 2011. Tese (Doutorado) - Université Lumière Lyon 2, Faculté de Sciences Économiques et de Gestion, 2011.

FARE, M.; FREITAS, C. de; MEYER, C. Community currencies in Brazilian community development banks: what role in territorial development? The case of Banco Palmas. In: INTERNACIONAL CONFERENCE ON SOCIAL AND COMPLEMENTARY CURRENCIES, 2., Haia, Holanda, Anais... Haia, 2013.

FAIRE Mouvement: synthèsis des débats. Rencontre Internationale des Acteurs des Monnaies Sociales et Complémentaires I (Relatório), 2012, Lyon, França. Disponível em: <monnaieendebat.org>. Acesso em 15 jan. 2013.

FRANÇA FILHO, G. C. et al. L'enjeu de le usage des monnaies sociales dans les banques communautaires de développement au Brésil: Etude du cas de la Banque Palmas. Revue Internationale de l'économie sociale (RECMA), Paris, n. 324, p. 70-86, 2012.

FRANÇA FILHO. G. C.; SILVA JR, J. T. Bancos Comunitários de Desenvolvimento (BCD). In: CATTANI, A. D. et al. Dicionário Internacional da Outra Economia: Edições Almedina, 2009. 31-37 p.

FREIRE, M. V. Moedas sociais: contributo em prol de um marco legal e regulatório para as moedas sociais circulantes locais no Brasil. 2011. Tese (Doutorado) - Programa de Pós-Graduação em Direito, Estado e Constituição da Universidade de Brasília (UNB), Brasília, 2011.
FREIRE, M. V. Social economy and central Banks: legal and regulatory issues on social currencies (social money) as a public policy instrument consistent whith monetary policy. International Journal of Community Currency Research, v. 13, p. 76-94, 2009.

GODBOUT, J. T. O espírito da dádiva. 1. ed. Rio de Janeiro: Fundação Getulio Vargas, 1999.

INSTITUTO PALMAS DE DESENVOLVIMENTO E SOCIOECONOMIA SOLIDÁRIA. Rede Brasileira de Bancos Comunitários, 2011. Disponível em < http://www.bancopalmas.org.br>. Acesso em: 20 maio 2011.

LIETAER, B.; KENNEDY, M. Monedas regionales: nuevos instrumentos para una prosperidad sustentable. s/l: La Hidra de Lerna Ediciones, 2010.

MARTIGNONI, J. A new approach to a typology of complementary currencies. International Journal Community Currency Research, v. 16, p. 01-17, 2012.

MENEZES, M. S. Moedas locais: uma investigação exploratória sobre seus potenciais como alternativa à exclusão financeira a partir do caso do Banco Bem em Vitória/ES. 2007. Dissertação (Mestrado) Cedeplar, Universidade Federal de Minas Gerais, Belo Horizonte, 2007.

MEYER, C. Les finances solidaires comme biens communs durables: étude de cas de la banque communautaire de dévelopment Palmas (Brésil). 2012. Memoire du Master, Faculte de sciences sociales et politiques, Université Libre de Bruxelle, 2012.

POLANYI, K. La subsistance de l'homme: La place de l'économie dans I'histoire et la société. Paris: Flamarion, 2011. [tradução do inglês de Bernard Chavance].

RIGO, A. S. Experiências distintas compartilhando sentidos: as moedas sociais no Brasil e na França. In: ENCONTRO ANUAL DOS PROGRAMAS DE PÓS GRADUAÇÃO EM ADMINISTRAÇÃO DA ANPAD, 37., Rio de Janeiro. Anais... Rio de Janeiro, 2013.

ROSPABÉ, P. A. La dette de la vie. Paris: Éditions La découverte/ Mauss, 1995.

SCHROEDER; R. F.; H; MIYAZAKI, Y.; FARE, M. Community currency research: an analysis of the literature. International Journal Community Currency Research (IJCCR), v. 15, n. section A, 201, p. 31-41, 2011.

SERVET, J-M. L'institution monétaire de la société selon Karl Polanyi. Revue économique, v. 44, n. 6, p. 1127-1150, 1993.

SILVA JÚNIOR, J. T. Gestão, fato associativo e economia solidária: a experiência da ASMOCONP/Banco Palmas. 2004. Dissertação (Mestrado) - Núcleo de Pós-Graduação em Administração da Universidade Federal da Bahia (NPGA/UFBA), Salvador, 2004.

SILVA JÚNIOR, J. T. Avaliação de impacto e de imagem: Banco Palmas 10 anos. Relatório Final. Juazeiro do Norte, 2008.

SOARES, C. L. B. Moeda social: uma análise interdisciplinar das suas potencialidades no Brasil contemporâneo. Tese (Doutorado) - Centro de Filosofia e Ciências Humanas, UFSC, Florianópolis, 2006. 
SOARES, C. L. B. Moeda Social. In: CATTANI, A. D. et al. Dicionário Internacional da Outra Economia. Coimbra: Edições Almedina, 2009. 255-259 p.

SOTIROPOULOU, I-C. Exchange networks and parallel currencies: Theoretical approuches and the case of Greece. 2012. Dissertação,
Escola de Ciências Sociais, Departamento de Economia, Universidade de Creta, Grécia, 2012.

THÉRET, B. Os três estados da moeda: abordagem interdisciplinar do fato monetário. Campinas, Economia e Sociedade, v. 17, n. 1 (32), p. 1-28, abr. 2008.

Ariádne Scalfoni Rigo

Doutora em Administração pela Universidade Federal da Bahia (UFBA); Professora adjunta na UFBA - Escola de Administração, Salvador, BA, Brasil. E-mail: ariadne.rigo@ufba.br 